NBER WORKING PAPER SERIES

\title{
THY NEIGHBOR'S PORTFOLIO: \\ WORD-OF-MOUTH EFFECTS IN THE \\ HOLDINGS AND TRADES OF MONEY MANAGERS
}

\author{
Harrison Hong \\ Jeffrey D. Kubik \\ Jeremy C. Stein \\ Working Paper 9711 \\ http://www.nber.org/papers/w9711 \\ NATIONAL BUREAU OF ECONOMIC RESEARCH \\ 1050 Massachusetts Avenue \\ Cambridge, MA 02138 \\ May 2003
}

Thanks to the National Science Foundation for research support, and to Rebecca Brunson and Ravi Pillai for research assistance. We are also grateful for comments and suggestions from Julian Abdey, Malcolm Baker, Gene D’Avolio, Chip Fortson, Rafael LaPorta, Karl Lins, Andrei Shleifer, and Jeff Wurgler, as well as from seminar participants at Harvard Business School, Boston College, the University of Texas, NYU, Columbia, Northwestern, Maryland, USC, Penn State and Syracuse. The views expressed herein are those of the authors and not necessarily those of the National Bureau of Economic Research.

(C2003 by Harrison Hong, Jeffrey D. Kubik, and Jeremy C. Stein. All rights reserved. Short sections of text not to exceed two paragraphs, may be quoted without explicit permission provided that full credit including (C) notice, is given to the source. 
Thy Neighbor's Portfolio: Word-of-Mouth Effects in the

Holdings and Trades of Money Managers

Harrison Hong, Jeffrey D. Kubik, and Jeremy C. Stein

NBER Working Paper No. 9711

May 2003

JEL No. D83, G11, G20

\section{$\underline{\text { ABSTRACT }}$}

A mutual-fund manager is more likely to hold (or buy, or sell) a particular stock in any quarter if other managers in the same city are holding (or buying, or selling) that same stock. This pattern shows up even when controlling for the distance between the fund manager and the stock in question, so it is distinct from a local-preference effect. It is also robust to a variety of controls for investment styles. These results can be interpreted in terms of an epidemic model in which investors spread information about stocks to one another by word of mouth.

Harrison Hong

Professor of Economics

Department of Economics

Princeton, NJ 08540-5296

hhong@princeton.edu

Jeremy C. Stein

Department of Economics

Harvard University

Littauer, Room 209

Cambridge, MA 02138

and NBER

jeremy_stein@harvard.edu
Jeffrey D. Kubik

Center for Policy Research

426 Eggers Hall

Syracuse University

Syracuse, NY 13244-1020

jdkubik@maxwell.syr.edu 


\section{Introduction}

In this paper, we explore the hypothesis that investors spread information and ideas about stocks to one another directly, through word-of-mouth communication. This hypothesis comes up frequently in informal accounts of the behavior of the stock market. ${ }^{1}$ For example, in his bestseller Irrational Exuberance, Shiller (2000) devotes an entire chapter to the subject of "Herd Behavior and Epidemics", and writes:

"A fundamental observation about human society is that people who communicate regularly with one another think similarly. There is at any place and in any time a Zeitgeist, a spirit of the times....Word-of-mouth transmission of ideas appears to be an important contributor to day-to-day or hour-to-hour stock market fluctuations..." (pp. 148, 155)

However, in spite of its familiarity, this hypothesis about word-of-mouth information transmission has received little direct support in stock-market data. ${ }^{2}$ One noteworthy exception is Shiller and Pound's (1989) survey of 131 individual investors. When asked about what had drawn their attention to the stock they had most recently purchased, many of these investors named a personal contact, such as a friend or relative. Although this evidence is certainly suggestive, it seems fair to say that the empirical case for the importance of word-of-mouth communication in the stock market has not yet been fully developed. ${ }^{3}$

In an effort to bring large-sample evidence to bear on the question, we study the holdings and trades of mutual-fund managers. Our empirical strategy is a simple one, premised on the

\footnotetext{
${ }^{1}$ See, e.g., Ellison and Fudenberg (1995) for a formal model of word-of-mouth learning.

${ }^{2}$ However, recent work has done much to advance the more general proposition that local peer-group effects can have important consequences for a number of other economic outcomes, including educational attainment and participation in crime. See, e.g., Case and Katz (1991), Glaeser, Sacerdote and Scheinkman (1996), and Bertrand, Luttmer and Mullainathan (2000); Glaeser and Scheinkman (2002) provide a survey with more references. Relatedly, Dumais, Ellison and Glaeser (2002) and Rosenthal and Strange (2001) provide evidence that geographic proximity facilitates intellectual spillovers across a variety of industries.

3 There are a few papers that look at word-of-mouth effects in other financial-market settings. Kelly and Grada (2000) find striking evidence that, during banking panics, bad news about banks spreads via word of mouth in neighborhoods. See also Duflo and Saez (2002) and Madrian and Shea (2000), who demonstrate that individuals' choices of retirement plans are influenced by the decisions of their co-workers.
} 
assumption that fund managers who work in the same city are more likely to come into direct contact with one another-e.g., at local investor conferences and other similar events — and hence to exchange ideas by word-of-mouth. Consider for example a fund manager working for the Fidelity fund family, which is located in Boston, and her decision of whether or not to buy shares of Intel in a given quarter. Our basic prediction is that this decision will be more heavily influenced by the decisions of fund managers working for the Putnam family, which is also located in Boston, than by the decisions of fund managers located in other cities.

This prediction is strongly confirmed in the data. The effects show up when we look at either the level of a fund manager's shareholdings in any given quarter, or the changes in her shareholdings from one quarter to the next-i.e., her trades. In terms of magnitudes, we find that, controlling for the holdings of the rest of the mutual-fund universe, a given fund manager's holdings of a particular stock (as a fraction of her total portfolio) increase by roughly 0.20 percent when other managers from different fund families in the same city increase their holdings of the same stock by one percent. So if managers at Putnam and other Boston-based fund families increase their average weighting on Intel from 1.0 percent of their portfolios to 2.0 percent, while other managers across the country keep their weightings fixed, we would expect the typical Fidelity manager to increase her weighting from 1.0 percent to about 1.20 percent.

Our tests control in a variety of ways for the distance between the fund manager and the company in question, so these results are distinct from the local-preference effect that Coval and Moskowitz (1999, 2001) have identified among mutual-fund managers. In other words, we are not just picking up the common factor that all Boston-based managers like to invest in Bostonarea companies. We also control for investment styles, as well as for industries. This means that 
our results do not just reflect a general tendency for all Boston-based managers to particularly favor, say, either small-cap value stocks, or biotech stocks.

While our analysis is perhaps most naturally motivated by the idea of direct word-ofmouth communication among investors, there are several other possible interpretations of our results, some of which are hard to rule out completely. For example, it might be that mutualfund managers in a given city read the local newspaper or watch a local TV station, and derive some of their investment ideas from this common source. While we cannot reject that this mechanism is partially responsible for our findings, we would argue that it is ultimately very close in spirit to the word-of-mouth channel, and interesting for many of the same reasons. In particular, in both cases, investors get their ideas from somebody who is physically nearbyeither a fellow investor, or a local business columnist who acts as a "town crier". And in both cases, the end result is that information about stocks diffuses gradually across the investing population, with the pattern of information diffusion governed by geographic proximity.

Another alternative story-which we call the "local-investor-relations (LIR) hypothesis"- is that fund managers get fed inside information directly by the managers of the companies they invest in, and that this privileged information distribution happens at the city level. ${ }^{4}$ For example, Intel may send a top executive on a road trip to Boston to brief Boston-area fund managers, either at a local conference, or in a series of one-on-one office visits. We think it is more worthwhile (and more feasible) to try to discriminate against this hypothesis, and we take some tentative steps in this direction.

\footnotetext{
${ }^{4}$ Yet another story-which we take up in more detail below-is that there is reputational herding of the sort described by Scharfstein and Stein (1990), but at the city level. Note that the empirical literature on herding (e.g., Chevalier and Ellison (1999), Hong, Kubik and Solomon (2000)) has not considered this possibility; instead it has focused on reputational forces that operate at the national level.
} 
One piece of evidence against the LIR hypothesis is that we get similar results before and after the implementation of Regulation Fair Disclosure (aka Reg FD), a set of disclosure rules that was approved by the Securities and Exchange Commission in the third quarter of 2000, and that requires a company to reveal any material information to all investors and analysts simultaneously. The intent of Reg FD is to prohibit exactly the kind of privileged information distribution that is envisioned in the LIR hypothesis. So to the extent that the regulation has any teeth, the fact that our results are not much changed by its implementation suggests that they are not just the product of an LIR effect. In a similar vein, our results carry over to very small firms with more retail-skewed shareholder bases and scanty analyst coverage, firms who presumably do less in the way of institutionally-targeted investor relations.

Although we do not claim to be able to completely dismiss the LIR hypothesis, it is again important to bear in mind that for some purposes, our results are of equal interest whether or not they are partially driven by an LIR effect. Consider the debate over how to explain the mediumhorizon momentum in stock returns first documented by Jegadeesh and Titman (1993). According to Barberis, Shleifer and Vishny (1998), and Daniel, Hirshleifer and Subrahmanyam (1998), momentum arises when the representative investor misreacts to a piece of information. In contrast, Hong and Stein (1999) and Hong, Lim and Stein (2000) argue that momentum comes from information that diffuses gradually across a heterogeneous set of investors. No matter which of the specific mechanisms discussed above is at work, our results would seem to be broadly supportive of the premise of gradual information diffusion. ${ }^{5}$ And importantly, these results help to put more structure on the process of information diffusion, suggesting that geography is an important determinant of who learns what when.

\footnotetext{
${ }^{5}$ See also Chan (2003) for further evidence on the gradual-information-diffusion hypothesis.
} 
Of course, the present analysis can at best only be loosely suggestive with respect to momentum and other asset-pricing patterns, since we look just at data on fund managers' holdings and trades, and do not show how these link up with stock returns. A related caveat is that in spite of the colorful quote from Shiller (2000) in the opening paragraph, our approach does not allow us to tell whether fund managers are passing on "irrationally exuberant" sentiment to their nearby colleagues, or real information about fundamentals.

Our approach to investor behavior in this paper builds on several earlier works. There is a close connection to Coval and Moskowitz $(1999,2001)$, who also study mutual-fund managers, and with whom we share the basic theme that physical proximity facilitates information transmission. ${ }^{6}$ The key distinction is that our interest is primarily in the information that investors who are close together can pass on to one another, whereas Coval and Moskowitz focus on the information that investors can gather about nearby companies. Our own previous work (Hong, Kubik and Stein (2003)) has begun to explore some of the consequences of social interaction for investment behavior, documenting that households who are more socially active are also more likely to invest in the stock market. But here we are looking at professional investors as opposed to households, with many more dollars at stake. Another advantage of the mutual-fund data is that we can see funds' decisions with respect to each of thousands of securities, which gives us a great deal of statistical power; in our previous paper we were limited to examining a household's single binary decision of whether or not to buy stocks at all.

The remainder of the paper is organized as follows. In Section II, we describe our data, as well as the econometric methodology we use. In Section III, we present our main results.

\footnotetext{
${ }^{6}$ Chen, Hong, Huang and Kubik (2002) and Christoffersen and Sarkissian (2002) also look at how mutual funds' locations affect their behavior. Petersen and Rajan (2002) and Berger, Miller, Petersen, Rajan and Stein (2002) are other papers that emphasize a similar theme, but in the context of commercial banks' lending to small companies.
} 
Section IV reviews some alternative interpretations of these results, and discusses our efforts to discriminate among them. Section V concludes.

\section{Data and Methodology}

Our data on mutual fund holdings come from CDA Spectrum. We augment this data in two ways. First, we associate each mutual fund with a fund family, and use Nelson's Directory of Investment Managers to establish the city in which the fund family is headquartered as of 1998. Second, for each stock, we use the Disclosure database to find the location of the company's headquarters.

The number of mutual funds that make it into our final sample is considerably smaller than the number of funds listed in the Spectrum database, for three reasons. First, we only retain those funds whose headquarters are in the U.S., and for whom we are able to find a family location in the Nelson's Directory. Second, we only consider those funds that are classified as stock funds. ${ }^{7}$ And third, we eliminate funds that do not have the same management company as the plurality of other funds in the same family. We do so because we infer that the management of these funds is contracted out, and hence may not take place in the same city as the family's headquarters. For example, one of the funds in the Vanguard family is the Wellington Fund, which is managed by the Wellington Management Co., whereas most Vanguard funds are managed by the Vanguard Group. And while the Vanguard family is headquartered in Philadelphia, the Wellington Management Co. is located in Boston. Because it is important for

\footnotetext{
${ }^{7}$ Stock funds are those in the Spectrum database with investment objective codes of 2, 3, 4 or 7, which correspond to aggressive-growth, growth, growth-and-income and balanced funds respectively.
} 
our purposes to know where fund managers actually are, observations like the Wellington Fund are a potentially problematic source of measurement error. ${ }^{8}$

After all of these screens, we are left with 1,715 funds in our baseline sample period of December 1998. ${ }^{9}$ Table 1 gives some basic information on the distribution across cities of those funds and fund families that are in our sample at this time. We rank cities by the number of fund families that they are home to. We also tabulate the number of individual funds in each city, as well as each city's share of the mutual-fund market, stated relative to both the total number of funds in our sample and the dollar value of all fund assets. As can be seen, New York and Boston dominate the mutual-fund landscape. New York has the most families, with 114, and its 462 funds represent 26.9 percent of the total of 1,715 funds in our sample as of December 1998. Boston has fewer families and funds (42 and 340 respectively), but a much larger share of total fund assets than New York, by a margin of 38.6 percent to 15.6 percent. This is due to the fact that some of the very largest mutual funds are located in Boston. Other major mutual-fund cities include Philadelphia (34 families, 5.6 percent of funds, 10.5 percent of total assets) and Los Angeles (26 families, 5.0 percent of funds, 10.8 percent of total assets).

In our baseline analysis, we look for peer group effects within the 15 "big" cities listed in Table 1, defined as those cities that have six or more mutual fund families: New York, Boston, Philadelphia, Chicago, San Francisco, Los Angeles, Minneapolis, Baltimore, Atlanta,

\footnotetext{
${ }^{8}$ We are grateful to several seminar participants for emphasizing this point to us. In an earlier draft of the paper, we did not have this last screen, which cuts down the number of funds in our sample by about 14 percent. Our results were qualitatively similar to those we report here, but - as might be expected from a measurement-error problemsignificantly smaller in magnitude, as well as more erratic on a city-by-city basis.

${ }^{9}$ This is roughly comparable to the number of funds that Coval and Moskowitz (2000) are left with after a similar selection procedure- they end up with 1,258 funds in 1994.
} 
Milwaukee, Houston, Miami, Tampa, Denver, and Kansas City. The idea of this six-family cutoff is that there needs to be several fund families in the same city in order for fund managers to have a meaningful chance to interact with others outside their own family. The rest of the mutual funds that are not located in one of these focal cities are lumped together in "Rest of Cities"; this category comprises 18.3 percent of the funds but only 5.5 percent of fund assets. We also perform sensitivity checks where we include either 10 or 25 focal cities in our analysis. As will be detailed below, these variations lead to very similar results.

Our estimation strategy proceeds as follows. First, we define our left-hand side variable, $h_{j, k, l}^{i}$ as the fractional share of its portfolio that mutual fund $j$, in family $k$, located in city $l$, holds in stock $i$. Note that $h_{j, k, l}^{i}$ is only defined for the 15 big cities that we focus on. We thus have an observation for every stock/big-city-fund pair in our sample. In particular, if we restrict ourselves to the top 2,000 stocks in the CRSP universe - as we do in our baseline analysis — and given that we have 1,402 funds (out of the total of 1,715 ) located in our big cities, there will be $2,804,000$ observations. Of course, many of these observations will be zeros, since most mutual funds only hold a small fraction of the available stocks.

Next, we define our right-hand-side variables. $H_{c}^{i}$ is the equally-weighted average across all funds in city $c$ of the share of funds' portfolios invested in stock $i$. In other words, $H_{c}^{i}$ measures how heavily invested in stock $i$ is the typical mutual fund in city $c$. Similarly, $H_{c, x k}^{i}$ is the equally-weighted average of the share of funds' portfolios invested in stock $i$, but where now the averaging is done across all funds in city $c$ except those in family $k$. Finally, $H_{R}^{i}$ is the equally-weighted average across all remaining funds-i.e., those funds not in one of our focal big cities — of the share of funds' portfolios invested in stock $i$. 
To control for the local bias effect identified by Coval and Moskowitz (1999), we define the dummy $L O C A L_{i, l}$, which takes on the value one if stock $i$ is headquartered in the same Census region as city $l$, and which takes on the value zero otherwise. ${ }^{10}$ Based on the findings of Coval and Moskowitz, we would expect $h_{j, k, l}^{i}$ to be positively correlated with $L O C A L_{i, l}$, which would just mean that funds have a propensity to invest more heavily in stocks that are headquartered close to their own home base.

Lastly, we need to define a couple of other indicator variables. We denote by $I(l=c)$ an indicator that takes on the value one if city $l$ and city $c$ are the same, and zero otherwise. And complementarily, we denote by $I(l \neq c)$ an indicator that takes on the value one if city $l$ and city $c$ are different. In other words, we have that $I(l \neq c)=(1-I(l=c))$.

We are now ready to write down our baseline specification. For any given quarter, we run the following cross-sectional ordinary-least-squares (OLS) regression:

$$
\begin{aligned}
h_{j, k, l}^{i}= & \sum_{c} \alpha_{c} \cdot\left\{H_{c, x k}^{i} \cdot I(l=c)\right\}+\sum_{c} \beta_{c} \cdot\left\{H_{c}^{i} \cdot I(l \neq c)\right\} \\
& +\gamma \cdot H_{R}^{i}+\delta \cdot L O C A L_{i, l}+\varepsilon_{j, k, l}^{i}
\end{aligned}
$$

This specification can be interpreted as follows. For each of our big cities of interest, we estimate two coefficients: an "own-city" effect given by the $\alpha_{c}$ 's, and an "other-city" effect given by the $\beta_{c}$ 's. For example, if Boston corresponds to $c=2$, then $\alpha_{2}$ measures how the holdings of a given Boston fund are influenced by the average holdings of other Boston funds not in the

\footnotetext{
${ }^{10}$ There are nine Census regions: New England (CT, ME, NH, RI, VT); Middle Atlantic (NJ, NY, PA); East North Central (IL, IN, MI, OH, WI); West North Central (IA, KS, MN, MO, NE, ND, SD); South Atlantic (DE, FL, GA, MD, NC, SC, VA, WV); East South Central (AL, KY, MS, TN); West South Central (AR, LA, OK, TX); Mountain (AZ, CO, ID, MT, NE, NM, UT, WY); and Pacific (AK, CA, HI, OR, WA).
} 
same family. And $\beta_{2}$ measures how the holdings of funds located in cities other than Boston are influenced by the average holdings of all Boston funds. The $\gamma \cdot H_{R}^{i}$ term allows the average holdings of the remaining funds - those not located in one of our focal big cities - to also have an influence on the holdings of any one of our big-city funds. And we have already mentioned the role of the $\delta \cdot L O C A L_{i, l}$ term, as a control for local bias.

Our key hypothesis is that the own-city effects should be larger than the other-city effects, i.e., that for any $c$, we should have $\alpha_{c}>\beta_{c}$. For example, we expect the holdings of a given Boston-based fund to be more responsive to the average holdings of other Boston funds (not in the same family) than would be the holdings of a fund located outside of Boston. To boil everything down to a single test statistic, we take the weighted average of the $\alpha_{c}$ 's, and compare it to the weighted average of the $\beta_{c}$ 's, with the weighting done according to the number of funds in each city. ${ }^{11}$

In addition to the baseline specification in (1), we also work with three variations. In the first of these, the $L O C A L_{i, l}$ term is replaced with fund-city*firm-Census-region dummies. With 15 fund cities and nine Census regions, we have 135 of these dummies. The idea here is to do an extremely conservative control for funds' geographic preferences. Rather than simply allowing a fund to have a preference for a stock that is headquartered nearby-i.e., in the same Census region-we now allow funds in any given city to have arbitrary geographic tastes. The motivation for doing so is the notion that some cities that are physically far apart (like, say, New York and Los Angeles) might conceivably be closer to one another in some economic-distance sense than other cities that are physically more proximate (like, say, New York and Buffalo).

\footnotetext{
${ }^{11}$ We have experimented with other weighting schemes, such as weighting by the dollar value of fund assets in each city. The results are very similar to those we report below.
} 
With our expanded set of geographic controls, if all funds in New York load up together on Pacific-region stocks, we will no longer attribute this to an own-city effect. Instead, we will only obtain an incremental own-city effect to the extent that all funds in New York tend to load up more on some particular Pacific-region stocks than on others.

In our second variation, we leave in the $L O C A L_{i, l}$ term, but add fund-city*investmentstyle dummies. These dummies are constructed as follows. First, each stock $i$ is assigned to one of five quintiles based on each of three characteristics: i) its current market capitalization; ii) its book-to-market ratio; and iii) its return momentum over the prior twelve months. ${ }^{12}$ We then create a set of 15 style dummies for each stock, which effectively capture its location in size/book-to-market/momentum space. ${ }^{13}$ Multiplying these 15 style dummies by dummies for each of the 15 fund cities gives us a total of 225 fund-city*investment-style dummies. With these controls in place, if all Boston funds load up together on, say, small growth stocks with positive momentum, we will no longer attribute this to an own-city effect. Rather, it will be dismissed as an element of "Boston style".

In our third variation, we replace the fund-city*investment-style dummies with fundcity*industry dummies. We have 1,245 of these, corresponding to 83 two-digit SIC codes multiplied by the 15 cities. The idea here is similar - now if all Boston funds load up on biotech stocks, we will again not credit this to an own-city effect. Of course, as with the style controls, this approach may well be too conservative, since it is likely that the word-of-mouth phenomenon that we are interested in sometimes takes the form of discussions about which styles or industries are likely to do well, as opposed to just individual stock tips.

\footnotetext{
${ }^{12}$ We sort on each of these three characteristics independently.

${ }^{13}$ For example, for a stock that ranked in the lowest quintile on each of the three characteristics, the 15 dummies would take on the values $\{1,0,0,0,0,1,0,0,0,0,1,0,0,0,0\}$.
} 
It is worth contrasting our baseline specification in (1) with a simpler and more intuitive alternative. Let $H_{M}^{i}$ denote the equally-weighted average across all funds of the share of funds' portfolios invested in stock $i$. One can run a regression of the form:

$$
h_{j, k, l}^{i}=a \cdot H_{c, x k}^{i} \cdot I(l=c)+b \cdot H_{M}^{i}+d \cdot L O C A L_{i, l}+\varepsilon_{j, k, l}^{i}
$$

According to the specification in (2), the degree to which a given fund deviates from typical market-wide weights (i.e., from $H^{i}{ }_{M}$ ) in its holdings of stock $i$ is allowed to be a function of the holdings of stock $i$ among other funds in the same city (but not the same family). In this set-up, the key test would be to ask whether $a>0$. While this approach sounds appealingly simple and straightforward, it suffers from a couple of drawbacks that lead us to prefer the more elaborate specification in (1).

First, specification (2) imposes the restriction that the influence of any given city on other cities-i.e., its weight in the market portfolio variable $H_{M}^{i}$-is proportional to the number of funds located there. It is not a priori obvious that this is the right assumption. For example, it might be that the influence of a city is determined instead by the dollar value of assets in funds located there, or by some other factors. By allowing the regression to pick out a different other-city coefficient (i.e., a different $\beta_{c}$ ) for each of our cities of interest, specification (1) is more flexible in this regard. ${ }^{14}$

\footnotetext{
${ }^{14}$ A related advantage of (1) is that it allows us to see whether each individual city is contributing in the right way to the overall results. That is, we can check if $\alpha_{c}>\beta_{c}$ in every city, something which cannot be done with (2).
} 
Second, and more significantly, specification (2) suffers from a double-counting problem that can become a source of bias to the extent that some of the biggest cities in our sample make up a substantial fraction of the entire mutual-fund universe. To see the nature of this problem, suppose that, consistent with a peer-effects story, all of the funds in New York together increase their holdings of a particular stock $i$, thereby raising the values of $h_{j, k, N Y}^{i}$ and $H_{N Y, x k}^{i}$. Ideally, we would like this sort of variation in the data to translate into a positive $a$ coefficient in a regression like (2). But since New York comprises a large fraction of the market portfolio, $H_{M}^{i}$ also goes up significantly. So the movement in $h_{j, k, N Y}^{i}$ is partially "explained" by the movement in $H_{M}^{i}$, reducing the apparent importance of $H_{N Y, x k}^{i}$, and hence shrinking our estimate of $a$ towards zero. Intuitively, since the New York portfolio (as represented by $H_{N Y, x k}^{i}$ ) and the market portfolio (as represented by $H_{M}^{i}$ ) are mechanically somewhat similar, the distinct influence of the New York portfolio is estimated with a downward bias. Specification (1) does not suffer from this doublecounting problem, since it never uses a single market portfolio variable $H_{M}^{i}$. Instead, the New York portfolio is simply allowed to enter with different weights when explaining the holdings of funds in New York and elsewhere.

In one of our robustness checks below, we experiment with using specification (2) in place of (1). As expected, the results are somewhat attenuated, in the sense that the estimate of the $a$ coefficient in (2) is smaller than the weighted average difference between the $\alpha_{c}$ 's and the $\beta_{c}$ 's in (1). But the difference is not big —on the order of five percent or so. Thus while specification (1) remains our preferred approach, it is not leading us to very different conclusions than we get with a much simpler alternative.

In spite of its advantages, specification (1) still suffers from another subtle bias that could lead us to understate the difference between the $\alpha_{c}$ 's and the $\beta_{c}$ 's. This bias arises when a single 
family represents a large share of the funds in a particular city. To see how it works, consider the case of Denver, where the Janus family controls 41 percent of all funds. Now suppose we take an observation of the left-hand side variable $h_{j, k, l}^{i}$ for a Janus fund-i.e., an observation for which $k=$ Janus and $l=$ Denver. When estimating the own-city " coefficient for Denver, $h_{j, k, l}^{i}$ will be matched up with $H_{c, x k}^{i}$, the share of non-Janus Denver funds' portfolios invested in stock $i$. In contrast, when estimating the other-city $\beta$ coefficient for Denver, non-Denver observations will be matched up with $H_{c}^{i}$, the share of all Denver funds' portfolios invested in stock $i$.

The problem is that the latter variable is simply more informative about what mutual funds in general are doing with respect to stock $i$, because in not excluding Janus funds, $H_{c}^{i}$ gives a more accurate picture of the "Denver portfolio". In other words, we would expect $H_{c}^{i}$ to do a better job of explaining the holdings of funds in an arbitrary other city (say Miami) than $H_{c, x k}^{i}$, where in this case $H_{c, x k}^{i}$ is the Denver portfolio excluding Janus. This effect pushes up the othercity coefficient for Denver relative to the own-city coefficient, and thereby reduces our estimate of the differential between the two.

We take a crude stab at mitigating this bias in another one of our robustness checks. We do so by discarding all the observations corresponding to those families who control more than 20 percent of the funds in their home city. In the context of the previous example, this means not using any observations from Janus funds on the left-hand side of the regression. At the same time, however, the holdings of Janus funds are still included in both the $H_{c}^{i}$ and $H_{c, x k}^{i}$ variables corresponding to Denver. Not surprisingly, this produces higher estimates of the own-city/othercity differential. But again, the differences relative to our baseline specification are modest. 


\section{Results}

\section{A. Baseline Results for Holdings}

Table 2 presents a detailed overview of our results for mutual-fund holdings in December of 1998. As noted above, our baseline sample includes the top 2,000 stocks in the CRSP universe, and all of the 1,402 funds in those 15 cities (shown in Table 1) that are home to six or more fund families. For each of the four specifications, we display all of the own-city and othercity coefficients (the $15 \alpha_{c}$ 's, and the $15 \beta_{c}$ 's respectively), as well as the local-bias coefficient $\delta$, and the rest-of-market coefficient $\gamma$. We also summarize the results by computing the weighted average of the difference between the $\alpha_{c}$ 's and the $\beta_{c}$ 's, with the weighting done according to the number of funds in each city. This weighted average differential is our key test statistic.

The numbers in the first set of columns correspond to our most basic specification, without either the geographic, style or industry dummies. The weighted average differential between the own-city coefficients and the other-city coefficients is 0.2172 , with a t-statistic of 12.07. ${ }^{15}$ This differential implies that for a given fund $j$, if all the other funds in $j$ 's city (but not in $j$ 's family) increase their holdings of a particular stock by one percentage point of total assets, then fund $j$ can be expected to increase its holdings of that stock by 0.2172 percentage points more than would an arbitrary fund in another city.

Turning to the city-by-city detail, we can see that the own-city effect exceeds the othercity effect in 14 of the 15 cities under consideration. The differences are statistically significant at the five-percent level in each of these 14 cases, and not significant in the one exceptionMilwaukee-where the comparison goes the other way. (To save space, the p-values for these tests are not shown in the table.) Moreover, even if one does not trust our standard errors, the

\footnotetext{
${ }^{15}$ The standard errors are adjusted to allow for correlation of observations within a given city.
} 
fact that the point estimates go the right way 14 out of 15 times is strong non-parametric evidence against the null hypothesis: an outcome of 14 or more heads has only a 0.0005 probability of occurring if a fair coin is flipped 15 times.

To get a sense of magnitudes, consider the following experiment. For each stock $i$, we have 15 observations of the average fund holdings at the city level, $H_{c}^{i}$. We demean these $H_{c}^{i}$ 's, allowing for a separate mean for each stock. With 2,000 stocks, this creates a pool of 30,000 residuals. The standard deviation of these residuals is 0.0635 percentage points. ${ }^{16}$ Thus if the other funds in $j$ 's city have portfolios that overweight stock $i$ by two standard deviations, then fund $j$ can be expected to overweight stock $i$ by 0.028 percentage points more than would a fund in another city $(0.0635 \times 2 \times 0.2172=0.028)$. As a benchmark, the mean fraction of its portfolio that a fund holds in any one stock is 0.042 percent. $^{17}$ So a two-standard-deviation shock to citylevel holdings has an incremental impact on fund $j$ 's holdings of stock $i$ that is about 67 percent of its unconditional mean $(0.028 / 0.042=0.67)$.

Our estimate of the local-bias coefficient $\delta$ is significantly positive, with a t-statistic of 2.37, confirming the findings of Coval and Moskowitz (1999). This coefficient implies that when a fund and a stock are located in the same Census region, the fund increases its holdings of that stock by 0.0064 percentage points of total assets, or by 15 percent of its unconditional mean holdings $(0.0064 / 0.042=0.15)$. Thus the impact of a two-standard-deviation change in citylevel holdings is roughly four times as big as the impact of a stock being local.

\footnotetext{
${ }^{16}$ In calculating this standard deviation, we weight observations of city-level residuals by the number of funds in the city. Our estimates of economic magnitudes are actually somewhat larger if we give each residual equal weight.

${ }^{17}$ To put this figure in perspective, recall that most funds have zero holdings of most stocks. So the mean holding conditional on actually owning a given stock is much higher.
} 
The next three sets of columns in Table 2 present analogous results for the cases where we add, in turn, the 135 fund-city*firm-Census-region dummies, the 225 fund-city*investmentstyle dummies, and the 1,245 fund-city*industry dummies. Each of these modifications reduces our weighted average estimate of the own-city/other-city differential somewhat, but still leaves it of the same basic magnitude. In the first case it falls from 0.2172 to 0.2119 (t-stat $=10.44)$, in the second case it falls to $0.2021(\mathrm{t}$-stat $=8.83)$, and in the third case it falls to $0.1804(\mathrm{t}$-stat $=$ 8.59). And it bears repeating that each of these adjustments should probably be thought of as excessively conservative.

\section{B. Probit Regressions}

Table 3 presents regressions that are identical in every way to those in Table 2, with one exception. We use probit instead of OLS, and the left-hand side variable is now dichotomous, taking on the value one if $h_{j, k, l}^{i}>0$, and the value zero if $h_{j, k, l}^{i}=0$. Thus we are asking to what extent our earlier results hold up when we look only at variation on the extensive margin (i.e., a fund going from non-ownership of a stock to ownership) as opposed to looking at variation on both the extensive and intensive margins simultaneously.

The results suggest that there is in fact a good deal of action on the extensive margin. In the first specification, the weighted average differential between the own-city coefficients and the other-city coefficients (now stated in terms of marginal effects) is 4.549 , with a t-statistic of 4.71. The general pattern again appears to be quite robust across cities, with the own-city effect being larger than the other-city effect in 13 of the 15 cities under consideration. In the two cities in which the comparison goes the other way (San Francisco and Milwaukee) the difference is not statistically significant. As before, adding the geographic, style and industry controls reduces the 
weighted average own-city/other-city differential, but not by very much: it is 4.026 (t-stat $=$ $6.41), 4.248(\mathrm{t}-\mathrm{stat}=5.25)$, and $3.231(\mathrm{t}$-stat $=5.05)$, respectively, for these three variations.

We can assess magnitudes in a manner analogous to what we have done above, again using the fact that the standard deviation of the demeaned $H_{c}^{i}$ 's is 0.0635 percentage points. Based on our first specification, this implies that if the other funds in $j$ 's city have portfolios that overweight stock $i$ by two standard deviations, then fund $j$ has a probability of owning stock $i$ that is 0.58 percent greater a fund in another city $(0.0635 \times 2 \times 4.549=0.58)$. The benchmark in this case is that the unconditional probability of a fund owning a stock is 4.31 percent. So a twostandard-deviation shock to city-level holdings has an incremental impact on fund $j$ 's propensity to hold stock $i$ that is about 13 percent of its unconditional mean $(0.58 / 4.31=0.13)$.

By way of comparison, our estimate of the local-bias coefficient $\delta$ implies that a fund has a 0.44 percent greater probability of owning a stock if that stock is local. As before, the localbias effect appears to be smaller than the effect of a two-standard-deviation change in city-level holdings, though the difference is less pronounced when we focus on the extensive margin.

\section{Different Samples and Specifications for Holdings Regressions}

In Table 4, we re-run our four basic holdings regressions, using a variety of alternative samples and specifications. In doing so, we revert back to our original OLS approach in Table 2, thereby considering variation in holdings on both the extensive and intensive margins. For the sake of brevity, we omit much of the detail shown in Tables 2 and 3, and for each regression only display the key summary statistic, the weighted average differential between the own-city coefficients and the other-city coefficients. Row 1 of Table 4 simply reproduces the summary numbers from our baseline regressions in Table 2 for easy reference. 
In Row 2, we keep the sample the same, but switch to using the simpler specification in (2). Here we report the $a$ coefficient, which is directly analogous to the weighted average difference between the $\alpha_{c}$ 's and the $\beta_{c}$ 's in specification (1). As can be seen, the numbers in this row are only slightly smaller than those from our baseline specification. For example, in the first column, with no added controls, the $a$ coefficient is 0.2092 , as compared to the figure of 0.2172 that we got when estimating specification (1).

In Row 3, we go back to specification (1), but drop all the observations corresponding to those "large" families who control more than 20 percent of the funds in their home cities. ${ }^{18}$ (We still use the holdings of these large families in the calculation of the $H_{c}^{i}$ and $H_{c, x k}^{i}$ variables). As discussed in Section II, this is a crude way of mitigating a bias in our methodology, one that might otherwise lead us to understate the own-city/other city differential. Consistent with this idea, the estimates are, across the board, slightly larger than before-e.g., with no added controls, the weighted average differential rises to 0.2253 .

In Row 4, we drop 76 index funds from the sample. ${ }^{19}$ The rationale for doing so is that the behavior of these funds is purely mechanical, and hence cannot be influenced by word-ofmouth considerations. Not surprisingly, this modification slightly increases our estimates. In Row 5, we combine the changes in Rows 3 and 4, dropping both large families and index funds. This yields our most aggressive set of estimates, ranging from 0.2311 in the regression with no further controls, to 0.1942 when we add the industry controls.

\footnotetext{
${ }^{18}$ The excluded families, along with their city shares, are as follows. Boston: Fidelity, 27\%; Los Angeles: Merrill Lynch, 23\%; Minneapolis: First American, 21\%; Baltimore: T. Rowe Price, 63\%; Milwaukee: Strong Capital, 37\%; Houston: AIM, 53\%; Miami: Templeton, 40\%, Mackenzie Financial, 27\% ; Tampa: Eagle Asset, 57\%; Denver: Janus, 41\%, Founders, 25\%; Kansas City: American Century, 42\%, Waddell \& Reed, 36\%.

${ }^{19}$ We define an index fund as any fund whose name contains the word "index", or some variant thereof. This is likely to underestimate the true number of funds that use indexing or quasi-indexing strategies.
} 
In Row 6, we keep everything else the same as in the baseline, but we exclude from the sample all local stocks-i.e., those for which $L O C A L_{i, l}=1$. In other words, we do not even consider funds' holdings of those stocks that are located in the same Census region as they are. This is a different approach than simply including a local dummy in the regression. The local dummy only controls for a fixed preference for local stocks. In contrast, by completely throwing out local stocks, we can address the following sort of possibility. Suppose that fund managers in a given city have better access to local executives, who feed them private informationsometimes positive, sometimes negative-about their companies. If fund managers act on this information, their holdings of individual local stocks will tend to move together, even if on average they show no net preference for these stocks. ${ }^{20}$

Of course, the flip side is that by excluding local stocks, we may also be suppressing some of the evidence that is most naturally supportive of word-of-mouth effects. After all, it is likely that fund managers would spend a disproportionate fraction of their time talking with one another about the prospects for local companies, even apart from any contact they might have with local executives. In any case, as can be seen in the table, the impact of this exclusion is small. In the first column, the own-city/other-city differential drops from 0.2172 to 0.2045 ; the declines across the other specifications are comparable in magnitude.

In Rows 7 and 8, we try changing the number of stocks under consideration. In Row 7 , we restrict ourselves to the top 1,000 stocks in the CRSP universe, and in Row 8 we expand to the top $3,000 .{ }^{21}$ In both cases, the estimates are very close to those from our baseline sample.

\footnotetext{
${ }^{20}$ Analogously, by excluding local stocks we also address the possibility that fund managers are responding to stories in the local media (newspaper, TV, etc.) that focus disproportionately on hometown companies.

${ }^{21}$ The market caps of the $1,000^{\text {th }}, 2,000^{\text {th }}$ and $3,000^{\text {th }}$ stocks in December of 1998 are $\$ 802.3$ million, $\$ 239.2$ million, and $\$ 97.9$ million, respectively.
} 
In Row 9, we look at an entirely new sample, composed of the 2,003 remaining microcap stocks that are below the top 3,000 (the median size in this group is $\$ 33.8$ million). A priori, it is not clear whether one should expect to find stronger or weaker effects among these tiny stocks. On the one hand, given that they tend to be less-well-covered by analysts and the media, it might seem that word-of-mouth information transmission would have a bigger role to play. On the other hand, we are looking for evidence of this word-of-mouth among institutional investors, and institutions tend to avoid the smallest stocks. ${ }^{22}$ As it turns out, the estimates for the microcap category are strongly significant. Indeed, the own-city/other-city differential is quite a bit bigger than in the larger-cap samples, with a value of 0.6889 in the first column. ${ }^{23}$

In Rows 10 and 11, we go back to using the top 2,000 stocks, and instead vary the number of cities that we deem big enough for inclusion. In Row 10, we tighten the screen, focusing only on the top 10 cities listed in Table 1; these cities all are home to at least 11 fund families. In Row 11, we loosen the screen, so that we allow into consideration the 25 cities with more than four fund families. In both cases, we obtain results that are almost identical to what we get in our 15-city base case.

Finally, in rows 12 through 14, we reproduce our 2,000-stock/15-city analysis for June 1998, as well as for December and June of $1997 .^{24}$ The numbers are stable period-to-period, and

\footnotetext{
${ }^{22}$ Using NYSE breakpoints, Gompers and Metrick (2001) report that the fraction of shares owned by institutions at year-end 1996 was $0.55,0.50,0.40,0.34$, and 0.13 for stocks in the largest through smallest market-cap quintiles respectively. Most of the stocks below the top 3,000 come from the smallest size quintile.

${ }^{23}$ However, a direct comparison of the point estimates can be especially misleading in this case, because there is much less variance in the right-hand-side variable among the micro-cap stocks - the standard deviation of the demeaned $H_{c}^{i}$ 's is now only 0.0048 percentage points, as opposed to its value of 0.0635 percentage points among the top 2,000 stocks.

${ }^{24}$ Although the Spectrum data is available quarterly, we do not use the March and September holdings in these regressions. A significant minority of funds (about a quarter of them) only report their holdings semi-annually, in June and December. If we want to use March and September data, we would have to exclude these funds. We take this approach when studying trades, because then it is obviously necessary to have quarterly data.
} 
those from December 1998 look to be fairly typical. Overall, across the four sample periods in 1997-98, the mean value of our summary statistic is 0.2093 for the baseline regression with no further controls - not far from the figure of 0.2172 that we report for December 1998. The results for the different periods are by no means independent, since there is a high degree of serial correlation in funds' holdings. Nevertheless, it seems clear that we can have more statistical confidence in our estimates than would be implied by just the t-statistics for any single crosssection viewed in isolation.

\section{Baseline Results for Trades}

We now turn our attention to funds' trades, as opposed to holdings. Our primary specification for trades is nothing more than a first-differenced version of equation (1), namely:

$\Delta h_{j, k, l, t}^{i}=\sum_{c} \alpha_{c} \cdot\left\{\Delta H_{c, x k, t}^{i} \cdot I(l=c)\right\}+\sum_{c} \beta_{c} \cdot\left\{\Delta H_{c, t}^{i} \cdot I(l \neq c)\right\}+\gamma \cdot \Delta H_{R, t}^{i}+\varepsilon_{j, k, l, t}^{i}$

where the $t$ subscripts have been added to make our timing conventions clearer. One noteworthy detail is that in calculating $\Delta h_{j, k, l, t}^{i}$ for any quarter $t$, we use only prices from quarter $t-1$. That is, for any stock $i$, we look at the change in the number of shares held between $t-1$ and $t$, and multiply this change by the price at $t-1$ in order to get the dollar change in holdings. The idea is to set aside any co-movements in measured trades across funds that are mechanically induced by price changes, rather than by their active buying and selling decisions. Note too that the differencing causes the local-bias term to drop out, and also removes any geographic, investment-style, or industry dummies. 
We also consider a couple of richer dynamic specifications, where we allow a given fund's trades in any quarter $t$ to be influenced by the trades of funds in its own and other cities in the prior quarters $t-1$ and $t-2$. For example, in the case where we only allow for one lag, the specification becomes:

$$
\begin{aligned}
& \Delta h_{j, k, l, t}^{i}=\sum_{c} \alpha_{c, 0} \cdot\left\{\Delta H_{c, x k, t}^{i} \cdot I(l=c)\right\}+\sum_{c} \beta_{c, 0} \cdot\left\{\Delta H_{c, t}^{i} \cdot I(l \neq c)\right\}+\gamma_{0} \cdot \Delta H_{R, t}^{i}+ \\
& \sum_{c} \alpha_{c, l} \cdot\left\{\Delta H_{c, x k, t-1}^{i} \cdot I(l=c)\right\}+\sum_{c} \beta_{c, l} \cdot\left\{\Delta H_{c, t-1}^{i} \cdot I(l \neq c)\right\}+\gamma_{1} \cdot \Delta H_{R, t-1}^{i}+\varepsilon_{j, k, l, t}^{i}
\end{aligned}
$$

where $\alpha_{c, 0}$ and $\beta_{c, 0}$ now denote the contemporaneous own-city and other-city coefficients for city $c$, while $\alpha_{c, 1}$ and $\beta_{c, 1}$ denote the once-lagged coefficients. The specification where we allow for two lags is set up analogously.

In contrast to our analysis of holdings, we now pool together the data from the eight quarters in 1997 and 1998 to run our regressions. Obviously, we need to string a few quarters together if we are to examine dynamics, as in (4). But even with the purely contemporaneous specification in (3), there is more of a gain in statistical power to doing this pooling, because the differenced data —i.e., the trades — are much closer to being independent from quarter to quarter than are the holdings. One consequence of requiring data from consecutive quarters is that the number of funds in our sample is reduced. This is because not all the mutual funds in the Spectrum database file holdings reports quarterly; approximately 24 percent of them only file semi-annually (in June and December) and hence must be dropped from the trades regressions.

Table 5 gives a detailed overview of our results for trades. We report all the coefficients for two OLS regressions: the contemporaneous version in (3), as well as the version in (4) that 
adds one lag. In the contemporaneous specification, we obtain a weighted average owncity/other-city differential of 0.1381 , with a t-statistic of 9.52 . This can be compared to the estimate of 0.2172 in the corresponding holdings regression. Thus not only do the holdings of a given fund track those of its same-city peers in levels, but it appears that much of the adjustment to changes in peers' holdings - roughly two-thirds — happens within the same quarter.

Moreover, as with the holdings regressions, the results here are again well-behaved across the individual cities. The own-city coefficient now exceeds the other-city coefficient in every one of the 15 cities, and in each case the difference is statistically significant at the five percent level or better. In terms of our non-parametric coin-flipping test, the probability of getting 15 heads in 15 flips is only 0.00003 .

In the specification that adds one lag, the contemporaneous differential is roughly unchanged, at 0.1402 , while the once-lagged differential (i.e., the weighted average value of $\alpha_{c, 1}$ minus $\beta_{c, 1}$ ) is much smaller, at 0.0120 , and not statistically significant. ${ }^{25}$ Thus the quarterly data appear to be too coarse for us to say much about the details of the dynamic adjustment process. Clearly, it would be nice to have higher-frequency data for this purpose.

\section{E. A Fama-MacBeth Analysis of Trades}

In a further effort to ensure that some unknown error-correlation structure is not leading us to overstate the statistical precision of our results, Table 6 takes a Fama-MacBeth (1973) approach to the analysis of trades. Rather than pooling all the data from 1997-1998 together into a single regression, we now estimate the contemporaneous-changes specification in (3) over

\footnotetext{
${ }^{25}$ A specification with two lags yields very similar results. In particular, the twice-lagged differential is again positive, but even smaller than the once-lagged differential.
} 
seven separate cross-sections, corresponding to the quarters ending between June 1997 and December 1998. Across these seven regressions, the mean value of the own-city/other-city differential is 0.1290 , and the median is 0.1192 . The highest value is 0.1850 , and the lowest is 0.0813. Based on the dispersion of these point estimates, the mean of 0.1290 has a FamaMacBeth standard error of 0.0143 , and an associated t-statistic of 9.02. Thus it appears that our prior inferences about precision have not been too aggressive.

\section{F. Different Samples and Specifications for Trades Regressions}

In Table 7, we explore the robustness of our trades results, using a format similar to that of Table 4. Given that we have not found any of the lagged differential terms to be statistically significant, we restrict attention in Table 7 to purely contemporaneous specifications. As can be seen, the outcomes here run closely parallel to those for holdings in Table 4. Perhaps the most noteworthy change is that the own-city/other-city differential shrinks some-from 0.1381 to 0.1168 - when we use a simple specification that is effectively a differenced version of (2). But overall, the numbers are remarkably stable across the different samples and specifications.

\section{Alternative Interpretations}

Our analysis has been motivated by the hypothesis that mutual-fund managers located in the same city engage in direct word-of-mouth communication with one another, sharing information and ideas about the stocks that they invest in. While the results thus far would appear to be consistent with this hypothesis, they also admit a couple of other alternative interpretations. We now discuss these alternative stories, and, where applicable, describe our efforts to discriminate amongst them. 


\section{A. The Local-Investor-Relations (LIR) Hypothesis}

As mentioned in the Introduction, one alternative possibility is that fund managers obtain inside information directly from the executives of the companies that they invest in, and that this privileged information distribution happens at the city level, either through conferences, road shows, or other forms of local investor relations activity. Although it is hard to completely rule out this LIR effect-and given its surface plausibility, it is not clear one would want to-it is possible to cobble together several pieces of evidence which, taken collectively, suggest that it is not the whole story behind our results.

Broadly speaking, our empirical strategy for discriminating against the LIR hypothesis is to look for alternative samples where we have good a priori reasons to think that investorrelations activity is likely to play a lesser role than in our baseline sample. If our results in these alternative samples are close to those in our baseline sample, we can have some confidence that these results are not entirely the product of an LIR effect.

We have already touched on two such experiments. First, recall that we have tried completely excluding all local stocks from our regressions. This variation is relevant in light of the LIR hypothesis, because to the extent that company executives pay visits to any fund managers at all, one would think that they would be especially inclined to visit nearby fund managers. In other words, investor relations activity should be most intense in a company's own backyard. Yet our estimates are hardly changed when we exclude local stocks.

Second, we have found that the basic results are robust among smaller stocks. Arguably, smaller companies should be expected to devote less in the way of resources to the sort of institutionally-oriented investor-relations activity that we have in mind here. For one thing, the 
fixed costs of such activity ought to loom larger to them. Moreover, small-cap-and especially micro-cap - companies have shareholder bases that are significantly less institutional on average, and more heavily tilted towards individual investors. ${ }^{26}$

A third way to address the LIR hypothesis is to make use of a recent regulatory change. As noted in the Introduction, Reg FD, which was approved by the SEC on August 10, 2000, and which became effective as of October 23,2000 , is intended precisely to reduce the extent to which company executives can selectively communicate information to a subset of their investors. Reg FD specifically requires a company to reveal any material information to all investors and Wall Street analysts simultaneously in the case of intentional disclosures, and within 24 hours in the case of unintentional disclosures.

There is some evidence that Reg FD has accomplished its objectives. In a recent survey by the Association for Investment Management Research (2001), about 90 percent of sell-side analysts reported holding individual interviews with top company managers prior to Reg FD, but roughly 70 percent of these analysts reported a drop in such contact post Reg FD. Other surveys reported in Agarwal and Chadha (2002) and Zitzewitz (2002) indicate that analysts and other institutional investors believe that their forecasts and recommendations to clients have been substantially impaired by Reg FD, and that Reg FD has led chief financial officers to reduce both the quality and quantity of their investor-communications efforts.

In the spirit of an event study, we would like to see if our basic results hold up in the immediate aftermath of Reg FD. Of course, any fund's holdings are highly serially correlated,

\footnotetext{
${ }^{26}$ As noted above, most of the stocks below the top 3,000 come from the smallest quintile based on NYSE breakpoints. Gompers and Metrick (2001) report that the fraction of shares owned by institutions in this quintile is 0.13 as of year-end 1996. This contrasts with a figure of 0.55 for the top market-cap quintile. Relatedly, 47 percent of firms in our sub-3,000 category have no analyst coverage at all. Even in the 2,000-to-3,000 class, the median number of analysts is only two, and 25 percent of firms have no coverage.
} 
which means that we cannot learn too much from redoing our holdings regressions for, e.g., December of 2000 and comparing these to the December 1998 holdings regressions. But a fund's trades are much more independent from quarter to quarter, so we do the following. We run the contemporaneous version of the trades regression given in equation (3), over two further intervals: i) September 2000 to December 2000; and ii) December 2000 to March 2001. ${ }^{27}$ These regressions are directly comparable to those reported in the Fama-MacBeth analysis of Table 6 .

Interestingly, we get fairly similar results: the own-city/other-city differential is 0.0902 (standard error of 0.0169) for the fourth quarter of 2000, and 0.0958 (standard error of 0.0189) for the first quarter of 2001. Recall that across the seven regressions in Table 6, we found a mean differential of 0.1290, and a median of 0.1192. Thus while the post-Reg-FD estimates are smaller than the pre-Reg-FD mean and median, the differences are neither economically large nor statistically significant. If one believes that Reg FD has had a real impact on what executives can selectively disclose to fund managers - and the survey evidence suggests that it has - this finding would seem to suggest that the LIR effect is not of first-order importance.

\section{B. Reputational Herding at the City Level}

Another alternative explanation for our results begins with a career-concerns-type herding model of the sort developed by Scharfstein and Stein (1990). In this setting, one mutual-

\footnotetext{
${ }^{27}$ One might take issue with the first of these two intervals, since Reg FD only became effective in the middle of the fourth quarter of 2000. However, Zitzewitz (2002) argues that Reg FD actually had its maximal impact in this quarter, in part because of the perception that it would be more vigorously enforced during the remaining tenure of its chief proponent, Arthur Levitt, at the SEC. Note too that as we move further away from our baseline sample period of December 1998, the coefficients become less directly comparable across regressions. One problem is that our data on funds' locations is as of December 1998. So we have to discard all those that come into existence after this date, which implies that we lose an increasing fraction of the fund universe the farther forward we go in time.
} 
fund manager might mimic the actions of another not because she learns anything useful from talking with him, but rather because she is afraid that doing something different might be harmful to her labor-market reputation. To date, all the empirical applications of this theory to the mutual-fund industry (e.g., Chevalier and Ellison (1999)) have construed the labor market in question to be a national one. In other words, the empirical work has implicitly assumed that any given fund manager has an equal incentive to mimic those in cities close to herself, and those further away. But one can imagine reformulating the theory slightly so that there is a greater incentive to mimic those close by. If fund managers tend to have limited mobility across cities, then a Boston-based manager's wage may be more closely linked to her relative standing in the Boston community than to her relative standing in the national community.

To put the distinction with the word-of-mouth model most sharply, observe that this version of the reputational herding mechanism can in principle apply even if all fund managers across the country have access to the same information. A Boston-based manager can know just as much about what Los Angeles managers are doing (and why they are doing it) as she knows about other Boston managers, but she will still tend to follow the Boston managers more closely because they are the ones that she is being benchmarked against.

However, it is also possible to construct stories that combine elements of both the reputational herding and word-of-mouth theories. For example, it might be that the labor market is a national one, so that for reputational reasons, a given manager only cares about her performance relative to those of all others in the industry. But at the same time, she might find it easier to get prompt information about what nearby managers are doing, so in her efforts to mimic current industry-wide holdings, she ends up with a portfolio that is especially close to those of managers who are located in the same city. 
These sorts of hybrid stories suggest that it will be difficult to construct tests that can sharply discriminate between reputational herding and word-of-mouth effects in the mutual-fund data. Following e.g., Chevalier and Ellison (1999), one might try to make some progress by adopting the identifying assumption that the incentives for reputational herding are greatest among younger money managers. But suppose that one then finds that younger managers are indeed the most prone to mimic the holdings and trades of their same-city counterparts. While this would be consistent with reputational herding playing some role in our results, it would not in any way rule out the importance of word-of-mouth communication, for the reasons outlined above. That is, it may be that reputational herding among young managers plays itself out at the city_rather than national-level precisely because word-of-mouth information transmission makes it easier to implement a strategy of copying those who are close by.

\section{Conclusions}

Our basic findings are easily summarized. The stockholdings (trades) of any given fund manager respond more sensitively to the holdings (trades) of other managers in the same city than to the holdings (trades) of fund managers in other cities. This regularity is distinct from a local-preference effect-indeed, it emerges even when local stocks are excluded from the analysis - and it is robust to stringent controls for investment styles. The own-city/other-city differential is also pronounced across a wide range of market-cap categories.

This paper can be seen as part of a small recent literature that examines how word-ofmouth effects influence behavior in various financial-market settings, joining, e.g., Duflo and Saez (2002), Madrian and Shea (2000), Kelly and Grada (2000) and Hong, Kubik and Stein (2003). However, one important distinction is that we do not know of any previous work that 
has posed the word-of-mouth question in the context of professional money managers. In the spirit of our opening quote from Shiller (2000), one of the main reasons to be interested in the word-of-mouth phenomenon in the first place is the possibility that it might ultimately have nontrivial implications for stock prices. But if one is only ever able to find evidence of word-ofmouth behavior among individuals, there will always be the objection that individuals are by themselves unlikely to exert a significant influence on stock prices, given the potentially powerful offsetting effects of professional arbitrage. Of course, our findings for professional money managers do not by themselves establish a link between word-of-mouth communication and stock prices. The only hope is that they leave the door open a bit wider than it was before, and thereby encourage further work on this topic.

A second reason why our results might be of particular interest is that—regardless of the precise interpretation - they hint at an explanation for the apparent tendency of stock prices to underreact to information, as in the momentum effect of Jegadeesh and Titman (1993). Hong and Stein (1999) and Hong, Lim and Stein (2000) argue that momentum comes from information that diffuses gradually across the investing public. Yet they do not spell out the underlying frictions that might lead information to spread slowly. Our evidence suggests that physical distance may be one such friction-i.e., that investors who are spatially separated behave as if they have access to different information sets. ${ }^{28}$ This conclusion applies no matter whether our results reflect fund managers in a given city either: i) talking to each other; ii) watching the same local TV news; or iii) talking to the same visiting company executives.

\footnotetext{
${ }^{28}$ In this regard we are echoing the main theme of Coval and Moskowitz $(1999,2001)$.
} 
Again, any attempt to draw a link between our findings and stock-return patterns such as momentum must be regarded as speculative at this point. At the same time, it seems like a natural and appealing goal for future work would be to try to make these sorts of connections more explicit. 


\section{References}

Agarwal, Anup, and Sahiba Chadha, 2002, Who is afraid of Reg FD? The behavior and performance of sell-side analysts following the SEC's Fair Disclosure rules, University of Alabama working paper.

Association for Investment Management Research, 2001, Regulation FD e-survey summary, available at http://www.aimr.com/pressroom/01releases/regfd_surveysum.htm.

Barberis, Nicholas, Andrei Shleifer and Robert Vishny, 1998, A model of investor sentiment, Journal of Financial Economics 49, 307-343.

Berger, Allen N., Nathan H. Miller, Mitchell A. Petersen, Raghuram G. Rajan, and Jeremy C. Stein, 2002, Does function follow organizational form? Evidence from the lending practices of large and small banks, Harvard University working paper.

Bertrand, Marianne, Erzo Luttmer, and Sendhil Mullainathan, 2000, Network effects and welfare cultures, Quarterly Journal of Economics 115, 1019-1055.

Case, Anne, and Lawrence Katz, 1991, The company you keep: The effect of family and neighborhood on disadvantaged youths, NBER working paper.

Chan, Wesley S., 2003, Stock price reaction to news and no-news: Drift and reversal after headlines, Journal of Financial Economics, forthcoming.

Chen, Joseph, Harrison Hong, Ming Huang and Jeffrey D. Kubik, 2002, Does fund size erode mutual fund performance? The role of liquidity and organization, Stanford University working paper.

Chevalier, Judith A., and Glenn D. Ellison, 1999, Career concerns of mutual fund managers, Quarterly Journal of Economics 114, 389-432.

Christoffersen, Susan and Sergei Sarkissian, 2002, Location overconfidence, McGill University working paper.

Coval, Joshua D., and Tobias J. Moskowitz, 1999, Home bias at home: Local equity preference in domestic portfolios, Journal of Finance 54, 2045-2073.

Coval, Joshua D., and Tobias J. Moskowitz, 2001, The geography of investment: Informed trading and asset prices, Journal of Political Economy 4, 811-841.

Daniel, Kent, David Hirshleifer, and Avanidhar Subrahmanyam, 1998, A theory of overconfidence, self-attribution and security market under- and over-reactions, Journal of Finance 53, 1839-1885. 
Duflo, Esther, and Emmanuel Saez, 2002, Participation and investment decisions in a retirement plan: The influence of colleagues' choices, Journal of Public Economics 85, 121-148.

Dumais, Guy, Glenn D. Ellison, and Edward L. Glaeser, 2002, Geographic concentration as a dynamic process, Review of Economics and Statistics 84, 193-204.

Ellison, Glenn D., and Drew Fudenberg, 1995, Word of mouth communication and social learning, Quarterly Journal of Economics 110, 93-125.

Fama, Eugene F., and James D. MacBeth, 1973. Risk, return, and equilibrium: Empirical tests, Journal of Political Economy 81, 607-636.

Glaeser, Edward L., Bruce Sacerdote, and Jose Scheinkman, 1996, Crime and social interactions, Quarterly Journal of Economics 111, 502-548.

Glaeser, Edward L., and Jose Scheinkman, 2002, Non-market interactions, in M. Dewatripont, L.P. Hansen and S. Turnovsky (eds), Advances in Economics and Econometrics: Theory and Applications, Eighth World Congress, Cambridge University Press.

Gompers, Paul A., and Andrew Metrick, 2001, Institutional investors and equity prices, Quarterly Journal of Economics 116, 229-259.

Hong, Harrison, Jeffrey D. Kubik, and Amit Solomon, 2000, Security analysts' career concerns and the herding of earnings forecasts, RAND Journal of Economics 31, 121-144.

Hong, Harrison, Jeffrey D. Kubik, and Jeremy C. Stein, 2003, Social interaction and stockmarket participation, Journal of Finance, forthcoming.

Hong, Harrison, Terence Lim, and Jeremy C. Stein, 2000, Bad news travels slowly: Size, analyst coverage, and the profitability of momentum strategies, Journal of Finance 55, 265-295.

Hong, Harrison, and Jeremy C. Stein, 1999, A unified theory of underreaction, momentum trading, and overreaction in asset markets, Journal of Finance 54, 2143-2184.

Jegadeesh, Narasimhan, and Sheridan Titman, 1993, Returns to buying winners and selling losers: Implications for stock market efficiency, Journal of Finance 48, 93-130.

Kelly, Morgan, and Cormac O. Grada, 2000, Market contagion: Evidence from the panics of 1854 and 1857, American Economic Review 90, 1110-1124.

Madrian, Brigette, and Dennis Shea, 2000, Peer effects and savings behavior in employer sponsored savings plans, University of Chicago working paper.

Petersen, Mitchell A., and Raghuram G. Rajan, 2002, Does distance still matter? The information revolution in small business lending, Journal of Finance, forthcoming. 
Rosenthal, Stuart S., and William C. Strange, 2001, The determinants of agglomeration, Journal of Urban Economics 50, 191-229.

Scharfstein, David S., and Jeremy C. Stein, 1990, Herd behavior and investment, American Economic Review 80, 465-479.

Shiller, Robert J., 2000, Irrational Exuberance, (Broadway Books: New York).

Shiller, Robert J., and John Pound, 1989, Survey evidence on diffusion of interest and information among investors, Journal of Economic Behavior and Organization 12, 4766.

Zitzewitz, Eric, 2002, Regulation Fair Disclosure and the private information of analysts, Stanford University working paper. 


\section{Table 1: Cities Ranked by Number of Fund Families, December 1998}

This table reports summary statistics on the distribution across cities of those funds and fund families that are in our sample as of December 1998. We rank cities by the number of fund families that they are home to. We also tabulate the number of individual funds in each city, as well as each city's share of the mutual-fund market, stated relative to both the total number of funds in our sample and the dollar value of all fund assets. We only retain those funds from the CDA Spectrum database whose headquarters are in the U.S., for whom we are able to find a family location in the Nelson's Directory, and that are classified as stock funds. We also discard those funds who have a management company that differs from that of the plurality of other funds in the same family. These screens leave us with a total of 1,715 funds in our baseline sample period of December 1998.

\begin{tabular}{llcccc}
\hline \multicolumn{1}{c}{ City } & $\begin{array}{c}\text { Number of } \\
\text { Fund Families }\end{array}$ & Number of Funds & \% of All Funds & $\begin{array}{c}\text { \% of All } \\
\text { Fund Assets }\end{array}$ \\
\hline 1 & New York & 114 & 462 & 26.9 & 15.6 \\
2 & Boston & 42 & 340 & 19.8 & 38.6 \\
3 & Philadelphia & 34 & 96 & 5.6 & 10.5 \\
4 & Chicago & 30 & 90 & 5.2 & 2.2 \\
5 & San Francisco & 27 & 70 & 4.1 & 1.5 \\
6 & Los Angeles & 26 & 86 & 5.0 & 10.8 \\
7 & Minneapolis & 15 & 47 & 2.7 & 0.6 \\
8 & Baltimore & 12 & 46 & 2.7 & 3.6 \\
9 & Atlanta & 12 & 12 & 0.7 & 0.3 \\
10 & Milwaukee & 11 & 35 & 2.0 & 1.1 \\
11 & Houston & 11 & 32 & 1.9 & 3.2 \\
12 & Miami & 8 & 15 & 0.9 & 0.1 \\
13 & Tampa & 7 & 8 & 0.5 & 0.0 \\
14 & Denver & 6 & 32 & 1.9 & 3.0 \\
15 & Kansas City & 6 & 31 & 1.8 & 3.5 \\
16 & Rest of Cities & 114 & 313 & 18.3 & 5.5 \\
\hline \hline
\end{tabular}




\section{Table 2: Own-City and Other-City Effects in Mutual Fund Holdings, December 1998}

This table reports results for OLS regressions corresponding to equation (1) of the text, along with three variations that include geographic controls, fund-style controls and industry controls respectively. The dependent variable is the percentage holding of a stock by a fund. Indicator for Local Stock takes on the value one if a stock is headquartered in the same Census region as the fund's family, and zero otherwise. The geographic controls are 15 fund-city dummies interacted with nine firm-Census-region dummies. The style controls are 15 fund-city dummies interacted with a set of 15 style dummies for each stock, which capture its location in size/book-to-market/return-momentum space. The industry controls are 15 fund-city dummies interacted with a set of 83 industry dummies (based on two-digit SIC codes). For each specification, we display all of the own-city and other-city coefficients (the $15 \alpha_{c}$ 's, and the $15 \beta_{c}$ 's respectively), as well as the rest-of-market coefficient $\gamma$, in Panel B. We also summarize the results by computing the weighted average of the difference between the $\alpha_{c}$ 's and the $\beta_{c}$ 's, with the weighting done according to the number of funds in each city. This weighted average differential is reported in Panel A, along with the local-bias coefficient $\delta$. Our sample includes the top 2,000 stocks in the CRSP universe, and all of the 1,402 funds in those 15 cities that are home to six or more fund families. The standard errors are adjusted to allow for correlation of observations within a city.

\section{Panel A: Summary}

\begin{tabular}{lc|c|c|c}
\hline & Baseline & Geographic Controls & Style Controls & Industry Controls \\
\hline Weighted Average Difference: & .2172 & .2119 & .2021 & .1804 \\
Own-City vs. Other-City Effects & $(.0180)$ & $(.0203)$ & $(.0229)$ & $(.0210)$ \\
Indicator for Local Stock $\times 100$ & .0064 & -0065 & .0071 & $(.0029)$ \\
& $(.0027)$ & & $(.0026)$ & No \\
Fund City $\times$ Firm Region Dummies & No & Yes & No & No \\
Fund City $\times$ Style Dummies & No & No & Yes & No \\
Fund City $\times$ Industry Dummies & No & No & & \\
\hline \hline
\end{tabular}




\begin{tabular}{|c|c|c|c|c|c|c|c|c|}
\hline & \multicolumn{2}{|c|}{ Baseline } & \multicolumn{2}{|c|}{ Geographic Controls } & \multicolumn{2}{|c|}{ Style Controls } & \multicolumn{2}{|c|}{ Industry Controls } \\
\hline & Own-City & Other-City & Own-City & Other-City & Own-City & Other-City & Own-City & Other-City \\
\hline New York & $\begin{array}{c}.4846 \\
(.0250)\end{array}$ & $\begin{array}{c}.2416 \\
(.0254)\end{array}$ & $\begin{array}{c}.4857 \\
(.0281)\end{array}$ & $\begin{array}{c}.2405 \\
(.0269)\end{array}$ & $\begin{array}{c}.4898 \\
(.0291)\end{array}$ & $\begin{array}{c}.2417 \\
(.0274)\end{array}$ & $\begin{array}{c}.4608 \\
(.0261)\end{array}$ & $\begin{array}{c}.2476 \\
(.0260)\end{array}$ \\
\hline Boston & $\begin{array}{c}.3022 \\
(.0348)\end{array}$ & $\begin{array}{c}.0687 \\
(.0320)\end{array}$ & $\begin{array}{c}.2974 \\
(.0343)\end{array}$ & $\begin{array}{c}.0690 \\
(.0320)\end{array}$ & $\begin{array}{c}.2807 \\
(.0328)\end{array}$ & $\begin{array}{c}.0691 \\
(.0325)\end{array}$ & $\begin{array}{c}.2755 \\
(.0392)\end{array}$ & $\begin{array}{c}.0727 \\
(.0352)\end{array}$ \\
\hline Philadelphia & $\begin{array}{c}.2027 \\
(.0257)\end{array}$ & $\begin{array}{c}.0362 \\
(.0129)\end{array}$ & $\begin{array}{c}.1898 \\
(.0255)\end{array}$ & $\begin{array}{c}.0374 \\
(.0124)\end{array}$ & $\begin{array}{c}.1486 \\
(.0228)\end{array}$ & $\begin{array}{c}.0359 \\
(.0126)\end{array}$ & $\begin{array}{c}.1646 \\
(.0267)\end{array}$ & $\begin{array}{c}.0400 \\
(.0129)\end{array}$ \\
\hline Chicago & $\begin{array}{c}.2647 \\
(.0281)\end{array}$ & $\begin{array}{c}.0316 \\
(.0148)\end{array}$ & $\begin{array}{c}.2628 \\
(.0276)\end{array}$ & $\begin{array}{c}.0321 \\
(.0150)\end{array}$ & $\begin{array}{c}.2651 \\
(.0253)\end{array}$ & $\begin{array}{c}.0330 \\
(.0153)\end{array}$ & $\begin{array}{c}.2127 \\
(.0298)\end{array}$ & $\begin{array}{c}.0326 \\
(.0183)\end{array}$ \\
\hline Los Angeles & $\begin{array}{c}.2161 \\
(.0319)\end{array}$ & $\begin{array}{c}.0449 \\
(.0178)\end{array}$ & $\begin{array}{c}.2026 \\
(.0312)\end{array}$ & $\begin{array}{c}.0458 \\
(.0176)\end{array}$ & $\begin{array}{c}.1544 \\
(.0281)\end{array}$ & $\begin{array}{c}.0435 \\
(.0203)\end{array}$ & $\begin{array}{c}.1641 \\
(.0342)\end{array}$ & $\begin{array}{c}.0460 \\
(.0198)\end{array}$ \\
\hline San Francisco & $\begin{array}{c}.1422 \\
(.0202)\end{array}$ & $\begin{array}{c}.0149 \\
(.0061)\end{array}$ & $\begin{array}{c}.1293 \\
(.0193)\end{array}$ & $\begin{array}{c}.0150 \\
(.0061)\end{array}$ & $\begin{array}{c}.1428 \\
(.0147)\end{array}$ & $\begin{array}{c}.0137 \\
(.0058)\end{array}$ & $\begin{array}{c}.1039 \\
(.0198)\end{array}$ & $\begin{array}{c}.0162 \\
(.0061)\end{array}$ \\
\hline Minneapolis & $\begin{array}{c}.3209 \\
(.0261)\end{array}$ & $\begin{array}{c}.0396 \\
(.0188)\end{array}$ & $\begin{array}{c}.3224 \\
(.0255)\end{array}$ & $\begin{array}{c}.0404 \\
(.0191)\end{array}$ & $\begin{array}{c}.3324 \\
(.0221)\end{array}$ & $\begin{array}{c}.0409 \\
(.0174)\end{array}$ & $\begin{array}{c}.2939 \\
(.0276)\end{array}$ & $\begin{array}{c}.0415 \\
(.0198)\end{array}$ \\
\hline Baltimore & $\begin{array}{c}.0883 \\
(.0165)\end{array}$ & $\begin{array}{c}.0167 \\
(.0097)\end{array}$ & $\begin{array}{c}.0654 \\
(.0148)\end{array}$ & $\begin{array}{c}.0184 \\
(.0094)\end{array}$ & $\begin{array}{c}.0587 \\
(.0113)\end{array}$ & $\begin{array}{c}.0183 \\
(.0099)\end{array}$ & $\begin{array}{c}.0258 \\
(.0155)\end{array}$ & $\begin{array}{c}.0194 \\
(.0080)\end{array}$ \\
\hline Atlanta & $\begin{array}{c}.3689 \\
(.0157)\end{array}$ & $\begin{array}{c}.0089 \\
(.0098)\end{array}$ & $\begin{array}{c}.3714 \\
(.0148)\end{array}$ & $\begin{array}{c}.0090 \\
(.0099)\end{array}$ & $\begin{array}{c}.3548 \\
(.0123)\end{array}$ & $\begin{array}{c}.0089 \\
(.0100)\end{array}$ & $\begin{array}{c}.3395 \\
(.0158)\end{array}$ & $\begin{array}{c}.0098 \\
(.0095)\end{array}$ \\
\hline Milwaukee & $\begin{array}{c}.0112 \\
(.0225)\end{array}$ & $\begin{array}{c}.0184 \\
(.0067)\end{array}$ & $\begin{array}{l}-.0324 \\
(.0218)\end{array}$ & $\begin{array}{c}.0196 \\
(.0062)\end{array}$ & $\begin{array}{l}-.0819 \\
(.0171)\end{array}$ & $\begin{array}{c}.0176 \\
(.0063)\end{array}$ & $\begin{array}{c}-.0775 \\
(.0229)\end{array}$ & $\begin{array}{c}.0200 \\
(.0071)\end{array}$ \\
\hline Houston & $\begin{array}{c}.1928 \\
(.0158)\end{array}$ & $\begin{array}{c}.0179 \\
(.0076)\end{array}$ & $\begin{array}{c}.1838 \\
(.0148)\end{array}$ & $\begin{array}{c}.0183 \\
(.0076)\end{array}$ & $\begin{array}{c}.1675 \\
(.0117)\end{array}$ & $\begin{array}{c}.0179 \\
(.0074)\end{array}$ & $\begin{array}{c}.1499 \\
(.0153)\end{array}$ & $\begin{array}{c}.0187 \\
(.0087)\end{array}$ \\
\hline Miami & $\begin{array}{c}.5364 \\
(.0063)\end{array}$ & $\begin{array}{c}.0051 \\
(.0036)\end{array}$ & $\begin{array}{c}.5482 \\
(.0054)\end{array}$ & $\begin{array}{c}.0050 \\
(.0036)\end{array}$ & $\begin{array}{c}.5677 \\
(.0040)\end{array}$ & $\begin{array}{c}.0049 \\
(.0036)\end{array}$ & $\begin{array}{c}.5323 \\
(.0058)\end{array}$ & $\begin{array}{c}.0053 \\
(.0039)\end{array}$ \\
\hline Tampa & $\begin{array}{c}.3521 \\
(.0068)\end{array}$ & $\begin{array}{c}.0020 \\
(.0068)\end{array}$ & $\begin{array}{c}.3531 \\
(.0058)\end{array}$ & $\begin{array}{c}.0019 \\
(.0069)\end{array}$ & $\begin{array}{c}.3716 \\
(.0043)\end{array}$ & $\begin{array}{c}.0018 \\
(.0069)\end{array}$ & $\begin{array}{c}.3021 \\
(.0060)\end{array}$ & $\begin{array}{c}.0010 \\
(.0063)\end{array}$ \\
\hline Denver & $\begin{array}{c}.2927 \\
(.0167)\end{array}$ & $\begin{array}{c}.0220 \\
(.0144)\end{array}$ & $\begin{array}{c}.2903 \\
(.0157)\end{array}$ & $\begin{array}{c}.0217 \\
(.0145)\end{array}$ & $\begin{array}{c}.2802 \\
(.0139)\end{array}$ & $\begin{array}{c}.0226 \\
(.0150)\end{array}$ & $\begin{array}{c}.2775 \\
(.0160)\end{array}$ & $\begin{array}{c}.0231 \\
(.0154)\end{array}$ \\
\hline Kansas City & $\begin{array}{c}.2400 \\
(.0183)\end{array}$ & $\begin{array}{c}.0225 \\
(.0093)\end{array}$ & $\begin{array}{c}.2336 \\
(.0175)\end{array}$ & $\begin{array}{c}.0227 \\
(.0096)\end{array}$ & $\begin{array}{c}.2175 \\
(.0139)\end{array}$ & $\begin{array}{c}.0223 \\
(.0091)\end{array}$ & $\begin{array}{c}.2080 \\
(.0179)\end{array}$ & $\begin{array}{c}.0236 \\
(.0086)\end{array}$ \\
\hline Rest of Market & & $\begin{array}{c}.1837 \\
(.0412)\end{array}$ & & $\begin{array}{c}.1835 \\
(.0410)\end{array}$ & & $\begin{array}{c}.1836 \\
(.0413)\end{array}$ & & $\begin{array}{c}.1917 \\
(.0420)\end{array}$ \\
\hline
\end{tabular}




\section{Table 3: Own-City and Other-City Effects in Mutual Fund Holdings: Probits, December 1998}

This table reports probit regressions analogous to the OLS regressions in Table 2. The dependent variable takes on the value one if a fund holds a given stock, and zero otherwise. Indicator for Local Stock takes on the value one if a stock is headquartered in the same Census region as the fund's family, and zero otherwise. The geographic controls are 15 fund-city dummies interacted with nine firm-Census-region dummies. The style controls are 15 fund-city dummies interacted with a set of 15 style dummies for each stock, which capture its location in size/book-to-market/return-momentum space. The industry controls are 15 fund-city dummies interacted with a set of 83 industry dummies (based on two-digit SIC codes). For each specification, we display all of the own-city and other-city marginal effects (the marginal effects of the $15 \alpha_{c}$ 's, and the $15 \beta_{c}$ 's respectively), as well as the marginal effect of the rest-of-market coefficient $\gamma$, in Panel B. We also summarize the results by computing the weighted average of the difference between the marginal effects of the $\alpha_{c}$ 's and the $\beta_{c}$ 's, with the weighting done according to the number of funds in each city. This weighted average differential is reported in Panel A, along with the marginal effect of the local-bias coefficient $\delta$. Our sample includes the top 2,000 stocks in the CRSP universe, and all of the 1,402 funds in those 15 cities that are home to six or more fund families. The standard errors are adjusted to allow for correlation of observations within a city.

\section{Panel A: Summary}

\begin{tabular}{|c|c|c|c|c|}
\hline & Baseline & Geographic Controls & Style Controls & Industry Controls \\
\hline $\begin{array}{l}\text { Weighted Average Difference: } \\
\text { Own-City vs. Other-City Effects }\end{array}$ & $\begin{array}{c}4.549 \\
(.9655)\end{array}$ & $\begin{array}{c}4.026 \\
(.6279)\end{array}$ & $\begin{array}{c}4.248 \\
(.8084)\end{array}$ & $\begin{array}{c}3.231 \\
(.6403)\end{array}$ \\
\hline Indicator for Local Stock & $\begin{array}{l}.0044 \\
(.0011)\end{array}$ & - & $\begin{array}{c}.0040 \\
(.0009)\end{array}$ & $\begin{array}{l}.0043 \\
(.0006)\end{array}$ \\
\hline Fund City $\times$ Firm Region Dummies & No & Yes & No & No \\
\hline Fund City $\times$ Style Dummies & No & No & Yes & No \\
\hline Fund City $\times$ Industry Dummies & No & No & No & Yes \\
\hline
\end{tabular}


Panel B: Details

\begin{tabular}{|c|c|c|c|c|c|c|c|c|}
\hline & \multicolumn{2}{|c|}{ Baseline } & \multicolumn{2}{|c|}{ Geographic Controls } & \multicolumn{2}{|c|}{ Style Controls } & \multicolumn{2}{|c|}{ Industry Controls } \\
\hline & Own-City & Other-City & Own-City & Other-City & Own-City & Other-City & Own-City & Other-City \\
\hline New York & $\begin{array}{c}8.975 \\
(1.930)\end{array}$ & $\begin{array}{c}5.511 \\
(1.033)\end{array}$ & $\begin{array}{c}9.930 \\
(1.330)\end{array}$ & $\begin{array}{c}5.027 \\
(.8341)\end{array}$ & $\begin{array}{c}13.35 \\
(.9672)\end{array}$ & $\begin{array}{c}6.594 \\
(.8487)\end{array}$ & $\begin{array}{c}9.402 \\
(1.295)\end{array}$ & $\begin{array}{c}5.315 \\
(.9115)\end{array}$ \\
\hline Boston & $\begin{array}{c}6.318 \\
(1.647)\end{array}$ & $\begin{array}{c}1.554 \\
(.7041)\end{array}$ & $\begin{array}{c}6.725 \\
(1.265)\end{array}$ & $\begin{array}{c}1.499 \\
(.7605)\end{array}$ & $\begin{array}{c}4.013 \\
(.9829)\end{array}$ & $\begin{array}{c}-1.188 \\
(.9506)\end{array}$ & $\begin{array}{c}5.947 \\
(1.340)\end{array}$ & $\begin{array}{c}1.414 \\
(.8610)\end{array}$ \\
\hline Philadelphia & $\begin{array}{c}17.85 \\
(2.104)\end{array}$ & $\begin{array}{c}3.478 \\
(1.088)\end{array}$ & $\begin{array}{c}5.645 \\
(1.147)\end{array}$ & $\begin{array}{c}4.392 \\
(.4713)\end{array}$ & $\begin{array}{c}.5220 \\
(.9379)\end{array}$ & $\begin{array}{c}1.565 \\
(.3586)\end{array}$ & $\begin{array}{c}5.083 \\
(1.123)\end{array}$ & $\begin{array}{c}4.603 \\
(.5016)\end{array}$ \\
\hline Chicago & $\begin{array}{c}-.2264 \\
(1.603)\end{array}$ & $\begin{array}{l}-1.607 \\
(.3279)\end{array}$ & $\begin{array}{c}-.7996 \\
(1.116)\end{array}$ & $\begin{array}{c}-1.612 \\
(.3199)\end{array}$ & $\begin{array}{c}2.032 \\
(.8450)\end{array}$ & $\begin{array}{c}-.3430 \\
(.3075)\end{array}$ & $\begin{array}{c}-.9127 \\
(1.118)\end{array}$ & $\begin{array}{c}-.8070 \\
(.3508)\end{array}$ \\
\hline Los Angeles & $\begin{array}{c}10.47 \\
(1.795)\end{array}$ & $\begin{array}{c}6.895 \\
(.7650)\end{array}$ & $\begin{array}{c}6.999 \\
(1.382)\end{array}$ & $\begin{array}{c}6.997 \\
(.7974)\end{array}$ & $\begin{array}{c}2.610 \\
(1.118)\end{array}$ & $\begin{array}{c}2.906 \\
(.6945)\end{array}$ & $\begin{array}{c}6.611 \\
(1.420)\end{array}$ & $\begin{array}{c}7.172 \\
(.8039)\end{array}$ \\
\hline San Francisco & $\begin{array}{c}.6795 \\
(1.343)\end{array}$ & $\begin{array}{c}.9097 \\
(.2801)\end{array}$ & $\begin{array}{c}1.514 \\
(.8728)\end{array}$ & $\begin{array}{c}.7900 \\
(.2649)\end{array}$ & $\begin{array}{c}-1.736 \\
(.5767)\end{array}$ & $\begin{array}{c}.2155 \\
(.2528)\end{array}$ & $\begin{array}{c}1.040 \\
(.8523)\end{array}$ & $\begin{array}{c}.9377 \\
(.2327)\end{array}$ \\
\hline Minneapolis & $\begin{array}{c}11.18 \\
(1.756)\end{array}$ & $\begin{array}{l}-1.829 \\
(.8583)\end{array}$ & $\begin{array}{c}8.043 \\
(1.311)\end{array}$ & $\begin{array}{c}-1.647 \\
(.7930)\end{array}$ & $\begin{array}{c}3.485 \\
(.9151)\end{array}$ & $\begin{array}{c}.4390 \\
(.6868)\end{array}$ & $\begin{array}{c}7.249 \\
(1.347)\end{array}$ & $\begin{array}{c}-1.891 \\
(.8463)\end{array}$ \\
\hline Baltimore & $\begin{array}{c}7.634 \\
(1.248)\end{array}$ & $\begin{array}{c}1.727 \\
(.4341)\end{array}$ & $\begin{array}{c}4.996 \\
(.7249)\end{array}$ & $\begin{array}{c}2.008 \\
(.3014)\end{array}$ & $\begin{array}{c}3.714 \\
(.4724)\end{array}$ & $\begin{array}{c}.6983 \\
(.2946)\end{array}$ & $\begin{array}{c}3.697 \\
(.6964)\end{array}$ & $\begin{array}{c}2.170 \\
(.2599)\end{array}$ \\
\hline Atlanta & $\begin{array}{c}7.563 \\
(.9340)\end{array}$ & $\begin{array}{c}1.856 \\
(.2579)\end{array}$ & $\begin{array}{c}10.14 \\
(.6547)\end{array}$ & $\begin{array}{c}1.837 \\
(.2561)\end{array}$ & $\begin{array}{c}10.70 \\
(.4709)\end{array}$ & $\begin{array}{c}1.451 \\
(.2555)\end{array}$ & $\begin{array}{c}9.301 \\
(.6495)\end{array}$ & $\begin{array}{c}1.847 \\
(.2201)\end{array}$ \\
\hline Milwaukee & $\begin{array}{c}1.610 \\
(1.553)\end{array}$ & $\begin{array}{c}4.320 \\
(.6888)\end{array}$ & $\begin{array}{c}4.476 \\
(.9745)\end{array}$ & $\begin{array}{c}4.145 \\
(.6715)\end{array}$ & $\begin{array}{c}.6215 \\
(.6429)\end{array}$ & $\begin{array}{c}1.087 \\
(.5183)\end{array}$ & $\begin{array}{c}3.321 \\
(.9607)\end{array}$ & $\begin{array}{c}4.409 \\
(.6194)\end{array}$ \\
\hline Houston & $\begin{array}{c}5.117 \\
(1.136)\end{array}$ & $\begin{array}{c}1.623 \\
(.4031)\end{array}$ & $\begin{array}{c}5.218 \\
(.7889)\end{array}$ & $\begin{array}{c}1.658 \\
(.4017)\end{array}$ & $\begin{array}{c}4.685 \\
(.5360)\end{array}$ & $\begin{array}{c}1.146 \\
(.3665)\end{array}$ & $\begin{array}{c}4.054 \\
(.7668)\end{array}$ & $\begin{array}{c}1.794 \\
(.3875)\end{array}$ \\
\hline Miami & $\begin{array}{c}1.967 \\
(.4565)\end{array}$ & $\begin{array}{c}.0038 \\
(.1042)\end{array}$ & $\begin{array}{c}3.723 \\
(.2784)\end{array}$ & $\begin{array}{c}-.0183 \\
(.0918)\end{array}$ & $\begin{array}{c}5.661 \\
(.1687)\end{array}$ & $\begin{array}{l}.1107 \\
(.0817)\end{array}$ & $\begin{array}{c}3.231 \\
(.2789)\end{array}$ & $\begin{array}{c}-.0962 \\
(.0965)\end{array}$ \\
\hline Tampa & $\begin{array}{c}1.885 \\
(.4952)\end{array}$ & $\begin{array}{l}.1870 \\
(.1815)\end{array}$ & $\begin{array}{c}4.200 \\
(.2719)\end{array}$ & $\begin{array}{l}.1500 \\
(.1685)\end{array}$ & $\begin{array}{c}6.390 \\
(.1599)\end{array}$ & $\begin{array}{c}.1326 \\
(.1716)\end{array}$ & $\begin{array}{c}3.403 \\
(.2576)\end{array}$ & $\begin{array}{c}.3618 \\
(.1815)\end{array}$ \\
\hline Denver & $\begin{array}{c}2.519 \\
(1.001)\end{array}$ & $\begin{array}{l}-.8072 \\
(.4100)\end{array}$ & $\begin{array}{c}4.670 \\
(.6591)\end{array}$ & $\begin{array}{l}-.8633 \\
(.3886)\end{array}$ & $\begin{array}{c}7.090 \\
(.4700)\end{array}$ & $\begin{array}{c}-.1402 \\
(.3683)\end{array}$ & $\begin{array}{c}4.179 \\
(.6406)\end{array}$ & $\begin{array}{l}-.8033 \\
(.4326)\end{array}$ \\
\hline Kansas City & $\begin{array}{c}9.920 \\
(1.144)\end{array}$ & $\begin{array}{c}2.061 \\
(.2095)\end{array}$ & $\begin{array}{c}10.84 \\
(.7688)\end{array}$ & $\begin{array}{c}1.965 \\
(.2250)\end{array}$ & $\begin{array}{c}10.23 \\
(.5169)\end{array}$ & $\begin{array}{c}1.696 \\
(.2064)\end{array}$ & $\begin{array}{c}9.669 \\
(.7560)\end{array}$ & $\begin{array}{c}1.662 \\
(.1898)\end{array}$ \\
\hline Rest of Market & & $\begin{array}{c}9.666 \\
(1.254) \\
\end{array}$ & & $\begin{array}{c}9.682 \\
(1.233) \\
\end{array}$ & & $\begin{array}{c}7.571 \\
(1.154) \\
\end{array}$ & & $\begin{array}{c}8.813 \\
(1.215) \\
\end{array}$ \\
\hline
\end{tabular}




\section{Table 4: Own-City and Other-City Effects in Mutual Fund Holdings: Various Samples and Specifications}

This table reports results for OLS regressions corresponding to equation (1) of the text (except in Row 2, where we use the simpler specification in equation (2)) along with three variations that include geographic controls, fundstyle controls and industry controls respectively. The dependent variable is the percentage holding of a stock by a fund. The geographic controls are 15 fund-city dummies interacted with nine firm-Census-region dummies. The style controls are 15 fund-city dummies interacted with a set of 15 style dummies for each stock, which capture its location in size/book-to-market/return-momentum space. The industry controls are 15 fund-city dummies interacted with a set of 83 industry dummies (based on two-digit SIC codes). For each regression, we summarize the results by computing the weighted average of the difference between the $\alpha_{c}$ 's and the $\beta_{c}$ 's, with the weighting done according to the number of funds in each city. The composition of the sample varies across the rows of the table, as indicated. The standard errors are adjusted to allow for correlation of observations within a city.

\begin{tabular}{|c|c|c|c|c|}
\hline & $\begin{array}{c}\text { Baseline } \\
\text { Model }\end{array}$ & $\begin{array}{c}\text { Geographic } \\
\text { Controls }\end{array}$ & $\begin{array}{c}\text { Style } \\
\text { Controls } \\
\end{array}$ & $\begin{array}{l}\text { Industry } \\
\text { Controls }\end{array}$ \\
\hline 1. Top 2000 Stocks, 15 Cities, Dec. 1998 & $\begin{array}{c}.2172 \\
(.0180)\end{array}$ & $\begin{array}{c}.2119 \\
(.0203)\end{array}$ & $\begin{array}{c}.2021 \\
(.0229)\end{array}$ & $\begin{array}{c}.1804 \\
(.0210)\end{array}$ \\
\hline 2. Simple Specification, Dec. 1998 & $\begin{array}{c}.2092 \\
(.0617)\end{array}$ & $\begin{array}{c}.2021 \\
(.0626)\end{array}$ & $\begin{array}{c}.1957 \\
(.0633)\end{array}$ & $\begin{array}{c}.1716 \\
(.0648)\end{array}$ \\
\hline 3. Excluding Large Families ( $>20 \%$ of a city), Dec. 1998 & $\begin{array}{c}.2253 \\
(.0269)\end{array}$ & $\begin{array}{c}.2203 \\
(.0300)\end{array}$ & $\begin{array}{c}.2151 \\
(.0319)\end{array}$ & $\begin{array}{c}.1828 \\
(.0303)\end{array}$ \\
\hline 4. Excluding Index Funds, Dec. 1998 & $\begin{array}{c}.2205 \\
(.0227)\end{array}$ & $\begin{array}{c}.2140 \\
(.0253)\end{array}$ & $\begin{array}{c}.2044 \\
(.0278)\end{array}$ & $\begin{array}{c}.1834 \\
(.0260)\end{array}$ \\
\hline 5. Excluding Index Funds and Large Families, Dec. 1998 & $\begin{array}{c}.2311 \\
(.0282)\end{array}$ & $\begin{array}{c}.2259 \\
(.0314)\end{array}$ & $\begin{array}{c}.2163 \\
(.0337)\end{array}$ & $\begin{array}{c}.1942 \\
(.0320)\end{array}$ \\
\hline 6. Excluding Local Stocks, Dec. 1998 & $\begin{array}{c}.2045 \\
(.0216)\end{array}$ & $\begin{array}{c}.1988 \\
(.0237)\end{array}$ & $\begin{array}{c}.1877 \\
(.0262)\end{array}$ & $\begin{array}{c}.1655 \\
(.0247)\end{array}$ \\
\hline 7. Top 1000 Stocks, 15 Cities, Dec. 1998 & $\begin{array}{c}.2243 \\
(.0179)\end{array}$ & $\begin{array}{c}.2150 \\
(.0218)\end{array}$ & $\begin{array}{c}.2035 \\
(.0233)\end{array}$ & $\begin{array}{c}.1563 \\
(.0234)\end{array}$ \\
\hline 8. Top 3000 Stocks, 15 Cities, Dec. 1998 & $\begin{array}{c}.2117 \\
(.0181)\end{array}$ & $\begin{array}{c}.2072 \\
(.0198)\end{array}$ & $\begin{array}{c}.1988 \\
(.0232)\end{array}$ & $\begin{array}{c}.1827 \\
(.0205)\end{array}$ \\
\hline 9. Micro-Caps (below Top 3000), 15 Cities, Dec. 1998 & $\begin{array}{c}.6889 \\
(.0786)\end{array}$ & $\begin{array}{c}.6680 \\
(.0815)\end{array}$ & $\begin{array}{c}.6419 \\
(.0843)\end{array}$ & $\begin{array}{c}.6276 \\
(.0827)\end{array}$ \\
\hline 10. Top 2000 Stocks, 10 Cities, Dec. 1998 & $\begin{array}{l}.2215 \\
(.0225)\end{array}$ & $\begin{array}{c}.2162 \\
(.0248)\end{array}$ & $\begin{array}{c}.2028 \\
(.0268)\end{array}$ & $\begin{array}{c}.1826 \\
(.0255)\end{array}$ \\
\hline 11. Top 2000 Stocks, 25 Cities, Dec. 1998 & $\begin{array}{c}.2104 \\
(.0162)\end{array}$ & $\begin{array}{c}.2080 \\
(.0178)\end{array}$ & $\begin{array}{c}.1985 \\
(.0209)\end{array}$ & $\begin{array}{c}.1758 \\
(.0180)\end{array}$ \\
\hline 12. Top 2000 Stocks, 15 Cities, June 1998 & $\begin{array}{l}.2252 \\
(.0158)\end{array}$ & $\begin{array}{c}.2187 \\
(.0177)\end{array}$ & $\begin{array}{c}.2134 \\
(.0204)\end{array}$ & $\begin{array}{l}.1905 \\
(.0184)\end{array}$ \\
\hline 13. Top 2000 Stocks, 15 Cities, Dec. 1997 & $\begin{array}{c}.2085 \\
(.0174)\end{array}$ & $\begin{array}{c}.2066 \\
(.0197)\end{array}$ & $\begin{array}{c}.2075 \\
(.0219)\end{array}$ & $\begin{array}{c}.1734 \\
(.0201)\end{array}$ \\
\hline 14. Top 2000 Stocks, 15 Cities, June 1997 & $\begin{array}{l}.1862 \\
(.0160)\end{array}$ & $\begin{array}{c}.1807 \\
(.0180) \\
\end{array}$ & $\begin{array}{c}.1745 \\
(.0199) \\
\end{array}$ & $\begin{array}{c}.1451 \\
(.0183) \\
\end{array}$ \\
\hline
\end{tabular}




\section{Table 5: Own-City and Other-City Effects in Mutual Fund Trades, March 1997-December 1998}

This table reports the results for OLS regressions corresponding to equations (3) and (4) of the text. The dependent variable is the change in the percentage holding of a stock by a fund. For the no-lag specification in (3), we report all of the own-city and other-city coefficients (the $15 \alpha_{c}$ 's, and the $15 \beta_{c}$ 's respectively), as well as the rest-of-market coefficient $\gamma$, in Panel B. We also summarize the results in Panel A, showing the weighted average of the difference between the $\alpha_{c}$ 's and the $\beta_{c}$ 's, with the weighting done according to the number of funds in each city. We also report in a similar manner the results for the specification in (4), which adds one lag. Here we show not only all of the contemporaneous own-city and other-city coefficients (the $15 \alpha_{c, 0}$ 's, and the $15 \beta_{c, 0}$ 's respectively) but also the corresponding lagged coefficients (the $15 \alpha_{c, 1}$ 's, and the $15 \beta_{c, 1}$ 's respectively). Our sample includes the top 2,000 stocks in the CRSP universe, and funds in those 15 cities that are home to six or more fund families. For a fund to be in the sample, it must report holdings data in consecutive quarters. The regressions pool all observations over the period of March 1997-December 1998. The standard errors are adjusted to allow for correlation of observations within a city.

Panel A: Summary

\begin{tabular}{lcrrr}
\hline & \multicolumn{2}{c}{ No Lags } & & \multicolumn{2}{c}{ One Lag } \\
\cline { 2 - 2 } & Contemporaneous Effect & & Contemporaneous Effect & One Quarter Lagged Effect \\
\hline Weighted Average Difference: & .1381 & & .1402 & .0120 \\
Own-City vs. Other-City Effects & $(.0145)$ & $(.0148)$ & $(.0101)$ \\
\hline \hline
\end{tabular}


Panel B: Details

\begin{tabular}{|c|c|c|c|c|c|c|}
\hline & \multirow{2}{*}{\multicolumn{2}{|c|}{$\begin{array}{c}\text { No Lags } \\
\text { Contemporaneous Effect }\end{array}$}} & \multicolumn{4}{|c|}{ One Lag } \\
\hline & & & \multicolumn{2}{|c|}{ Contemporaneous Effect } & \multicolumn{2}{|c|}{ One Quarter Lagged Effect } \\
\hline & Own-City & Other-City & Own-City & Other-City & Own-City & Other-City \\
\hline New York & $\begin{array}{l}.3285 \\
(.0111)\end{array}$ & $\begin{array}{c}.1814 \\
(.0137)\end{array}$ & $\begin{array}{l}.3439 \\
(.0108)\end{array}$ & $\begin{array}{l}.1930 \\
(.0142)\end{array}$ & $\begin{array}{l}-.0152 \\
(.0090)\end{array}$ & $\begin{array}{c}.0077 \\
(.0143)\end{array}$ \\
\hline Boston & $\begin{array}{l}.2669 \\
(.0073)\end{array}$ & $\begin{array}{l}.1236 \\
(.0157)\end{array}$ & $\begin{array}{l}.2671 \\
(.0090)\end{array}$ & $\begin{array}{l}.1234 \\
(.0156)\end{array}$ & $\begin{array}{c}.0600 \\
(.0090)\end{array}$ & $\begin{array}{l}-.0134 \\
(.0150)\end{array}$ \\
\hline Philadelphia & $\begin{array}{l}.2121 \\
(.0079)\end{array}$ & $\begin{array}{l}.0424 \\
(.0086)\end{array}$ & $\begin{array}{l}.2242 \\
(.0080)\end{array}$ & $\begin{array}{l}.0377 \\
(.0096)\end{array}$ & $\begin{array}{l}.0065 \\
(.0042)\end{array}$ & $\begin{array}{l}.0002 \\
(.0047)\end{array}$ \\
\hline Chicago & $\begin{array}{l}.1590 \\
(.0065)\end{array}$ & $\begin{array}{l}.0490 \\
(.0070)\end{array}$ & $\begin{array}{l}.1703 \\
(.0071)\end{array}$ & $\begin{array}{l}.0515 \\
(.0089)\end{array}$ & $\begin{array}{l}.0153 \\
(.0042)\end{array}$ & $\begin{array}{l}-.0054 \\
(.0051)\end{array}$ \\
\hline Los Angeles & $\begin{array}{l}.1219 \\
(.0057)\end{array}$ & $\begin{array}{l}.0424 \\
(.0061)\end{array}$ & $\begin{array}{l}.1236 \\
(.0056)\end{array}$ & $\begin{array}{c}.0405 \\
(.0070)\end{array}$ & $\begin{array}{l}-.0178 \\
(.0047)\end{array}$ & $\begin{array}{l}-.0014 \\
(.0057)\end{array}$ \\
\hline San Francisco & $\begin{array}{l}.1421 \\
(.0036)\end{array}$ & $\begin{array}{c}.0201 \\
(.0029)\end{array}$ & $\begin{array}{l}.1392 \\
(.0032)\end{array}$ & $\begin{array}{c}.0184 \\
(.0030)\end{array}$ & $\begin{array}{c}-.0023 \\
(.0023)\end{array}$ & $\begin{array}{l}-.0008 \\
(.0016)\end{array}$ \\
\hline Minneapolis & $\begin{array}{c}.1611 \\
(.0050)\end{array}$ & $\begin{array}{c}.0377 \\
(.0046)\end{array}$ & $\begin{array}{c}.1689 \\
(.0059)\end{array}$ & $\begin{array}{c}.0392 \\
(.0060)\end{array}$ & $\begin{array}{c}.0175 \\
(.0045)\end{array}$ & $\begin{array}{c}.0048 \\
(.0062)\end{array}$ \\
\hline Baltimore & $\begin{array}{c}.0797 \\
(.0024)\end{array}$ & $\begin{array}{c}.0234 \\
(.0114)\end{array}$ & $\begin{array}{c}.0689 \\
(.0026)\end{array}$ & $\begin{array}{c}.0228 \\
(.0132)\end{array}$ & $\begin{array}{l}-.0057 \\
(.0008)\end{array}$ & $\begin{array}{l}-.0015 \\
(.0024)\end{array}$ \\
\hline Atlanta & $\begin{array}{c}.3086 \\
(.0015)\end{array}$ & $\begin{array}{c}.0105 \\
(.0017)\end{array}$ & $\begin{array}{c}.2680 \\
(.0016)\end{array}$ & $\begin{array}{c}.0118 \\
(.0019)\end{array}$ & $\begin{array}{c}.0255 \\
(.0011)\end{array}$ & $\begin{array}{c}.0025 \\
(.0016)\end{array}$ \\
\hline Milwaukee & $\begin{array}{c}.0535 \\
(.0032)\end{array}$ & $\begin{array}{c}.0283 \\
(.0036)\end{array}$ & $\begin{array}{c}.0582 \\
(.0033)\end{array}$ & $\begin{array}{c}.0294 \\
(.0053)\end{array}$ & $\begin{array}{c}.0033 \\
(.0022)\end{array}$ & $\begin{array}{c}.0017 \\
(.0013)\end{array}$ \\
\hline Houston & $\begin{array}{c}.0767 \\
(.0006)\end{array}$ & $\begin{array}{c}.0033 \\
(.0031)\end{array}$ & $\begin{array}{c}.0855 \\
(.0007)\end{array}$ & $\begin{array}{c}.0031 \\
(.0031)\end{array}$ & $\begin{array}{c}.0015 \\
(.0003)\end{array}$ & $\begin{array}{c}.0012 \\
(.0007)\end{array}$ \\
\hline Miami & $\begin{array}{c}.4957 \\
(.0008)\end{array}$ & $\begin{array}{c}.0040 \\
(.0023)\end{array}$ & $\begin{array}{c}.4983 \\
(.0006)\end{array}$ & $\begin{array}{c}.0031 \\
(.0021)\end{array}$ & $\begin{array}{c}.0019 \\
(.0007)\end{array}$ & $\begin{array}{c}.0007 \\
(.0012)\end{array}$ \\
\hline Tampa & $\begin{array}{c}.2923 \\
(.0003)\end{array}$ & $\begin{array}{c}.0001 \\
(.0016)\end{array}$ & $\begin{array}{c}.2824 \\
(.0004)\end{array}$ & $\begin{array}{c}.0002 \\
(.0016)\end{array}$ & $\begin{array}{c}-.0003 \\
(.0003)\end{array}$ & $\begin{array}{c}-.0013 \\
(.0016)\end{array}$ \\
\hline Denver & $\begin{array}{c}.2526 \\
(.0022)\end{array}$ & $\begin{array}{c}.0155 \\
(.0025)\end{array}$ & $\begin{array}{c}.2457 \\
(.0027)\end{array}$ & $\begin{array}{c}.0172 \\
(.0027)\end{array}$ & $\begin{array}{c}-.0094 \\
(.0013)\end{array}$ & $\begin{array}{l}-.0021 \\
(.0030)\end{array}$ \\
\hline Kansas City & $\begin{array}{c}.1085 \\
(.0018)\end{array}$ & $\begin{array}{c}.0138 \\
(.0018)\end{array}$ & $\begin{array}{c}.1103 \\
(.0019)\end{array}$ & $\begin{array}{c}.0129 \\
(.0018)\end{array}$ & $\begin{array}{c}.0334 \\
(.0014)\end{array}$ & $\begin{array}{c}.0040 \\
(.0026)\end{array}$ \\
\hline Rest of Market & & $\begin{array}{c}.1210 \\
(.0074)\end{array}$ & & $\begin{array}{c}.1246 \\
(.0079)\end{array}$ & & $\begin{array}{c}.0034 \\
(.0084)\end{array}$ \\
\hline
\end{tabular}




\section{Table 6: Own-City and Other-City Effects in Mutual Fund Trades: Quarterly Fama-MacBeth Regressions}

This table reports Fama-MacBeth results for OLS regressions corresponding to equation (3) of the text. The dependent variable is the change in the percentage holding of a stock by a fund. For each quarter, we display the weighted average of the difference between the $\alpha_{c}$ 's and the $\beta_{c}$ 's, with the weighting done according to the number of funds in each city. Our sample includes the top 2,000 stocks in the CRSP universe, and funds in those 15 cities that are home to six or more fund families. For a fund to be in the sample, it must report holdings data in consecutive quarters.

$4^{\text {th }}$ Quarter 1998

$3^{\text {rd }}$ Quarter 1998

$2^{\text {nd }}$ Quarter 1998

$1^{\text {st }}$ Quarter 1998

$4^{\text {th }}$ Quarter 1997

$3^{\text {rd }}$ Quarter 1997

$2^{\text {nd }}$ Quarter 1997

Mean of Quarterly Estimates

(standard error of mean)
.1192

.1850

.1320

.1719

.1188

.0813

.0950

.1290

(.0143) 


\section{Table 7: Own-City and Other-City Effects in Mutual Fund Trades: Various Samples and Specifications}

This table reports results for OLS regressions corresponding to equation (3) of the text (except in Row 2 , where we use a differenced version of the simple specification in equation (2)). The dependent variable is the change in the percentage holding of a stock by a fund. We report the weighted average of the difference between the $\alpha_{c}$ 's and the $\beta_{c}$ 's, with the weighting done according to the number of funds in each city. For a fund to be in the sample, it must have holdings in consecutive quarters. The regressions pool all observations over the period March 1997-December 1998. The composition of the sample varies across the rows of the table, as indicated. The standard errors are adjusted to allow for correlation of observations within a city.

1. Top 2000 Stocks, 15 Cities

2. Simple Specification

3. Excluding Large Families ( $>20 \%$ of a city)

4. Excluding Index Funds

5. Excluding Index Funds and Large Families

6. Excluding Local Stocks

7. Top 1000 Stocks, 15 Cities

8. Top 3000 Stocks, 15 Cities

9. Micro-Caps (below Top 3000), 15 Cities

10. Top 2000 Stocks, 10 Cities

11. Top 2000 Stocks, 25 Cities 